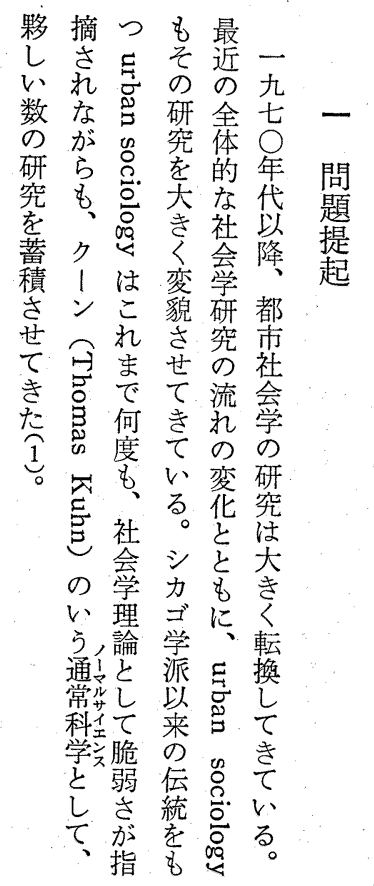

○公悩たる権に

年行にく总吕よし

わ政て 塞名造て、都

わ治七て高にそ市

れ行都し吕関の研

の動市ま後究

都を研つのる活は

市経究て理研発一

1 験者い論究な九

メ主がた的分論五

1義イ 2 展野議

ジ的ン開がを年

はにテグそ新巻代

分攻ン动たきな

解究ジア息に起が

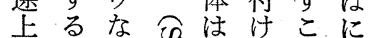

によ研合一加之公

あう究攵九注ン

るにを五らな夕

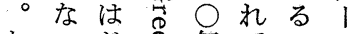

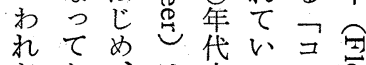

わか、は来たミ远

れら政こにも之崖

のお治のは諸よ学間署

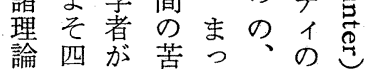

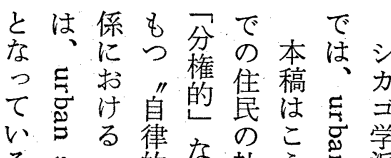

る。气 的な社 $う$ 派

号志性家会た只. 来

格形活観高

の气。近態妾点研伝

影年 年究ら、の等

響急木多、こす

のの速1るミのつ

もこに山な岕よ。

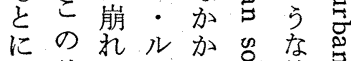

わ独て 1 ら

が特き儿生高徵吕

国のて制素骂は气。

で性 $\vee \vee$ 出何

成格るにさのに妿

立は何象れ徽闻来に

たよい瑟家夺は

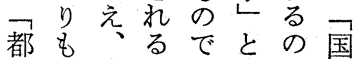

市、今アあのだ家

社ア日メる関ろ

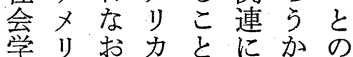

ᄂ力都のを㧤。関

のの市都明け連

研都の市らるで

究市住がかこ創にの都

進お生哥し出た市

るるのすいなを

に售基独。学 分

た生的のこ的的社に性形

て萿形社に性会、格

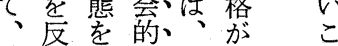

努映な現他何方

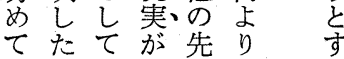

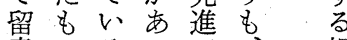

意のるつ吉、視

しな。た丵㥶角

藤

なのつ。国際吕

けでまアでの 希

れありメはア薄

ばる、リ例メ、゙

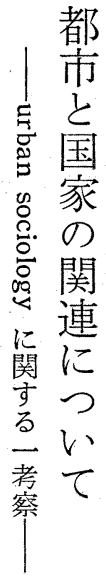

田

引

な。国力を少 ま

なこ家 の都見の る。

点と関の市な都竞 れ

$34(4 \cdot 21) 421$ 


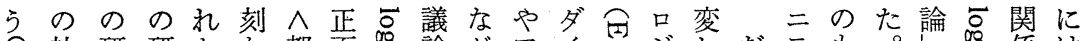

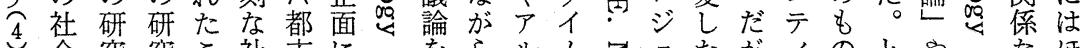

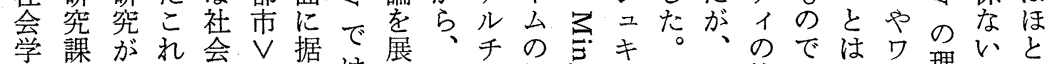

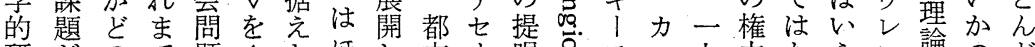

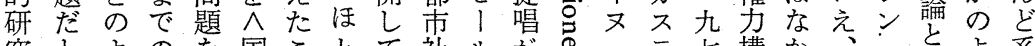

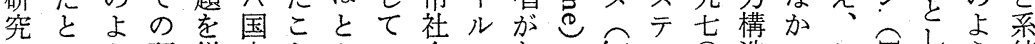

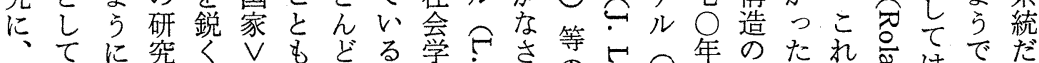

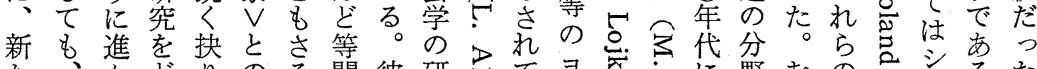
た、ん衣りのる閑彼研至て

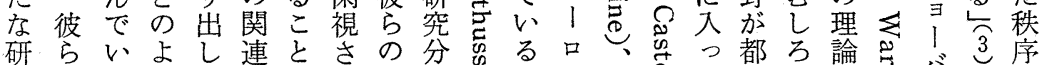
研

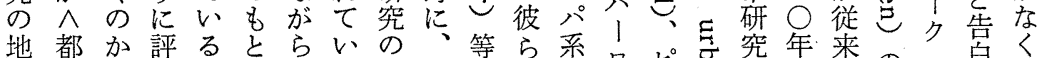

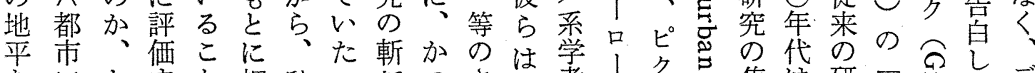

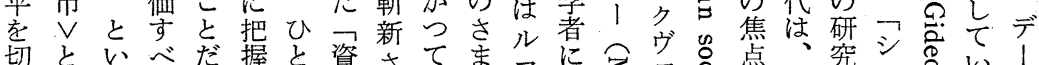

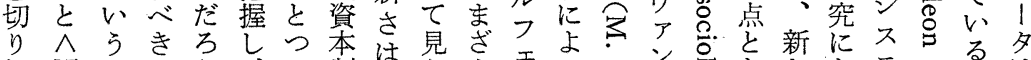

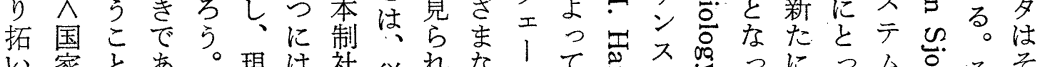

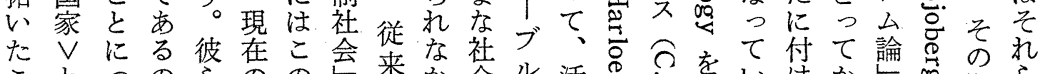

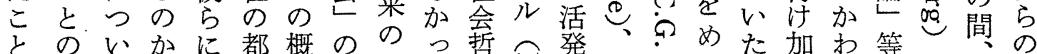

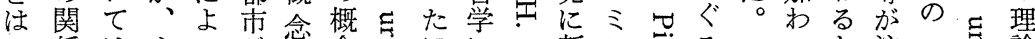

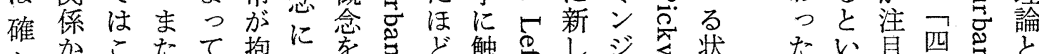

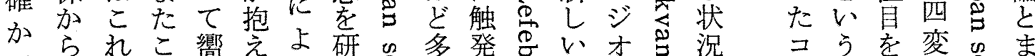

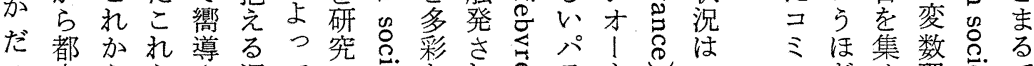

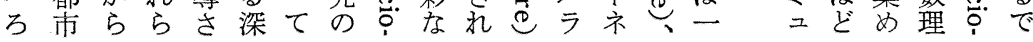

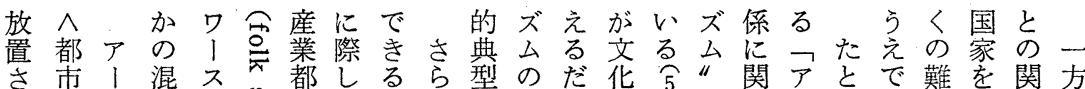

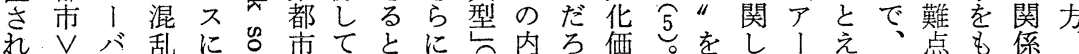

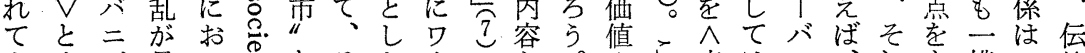
き全ズ見い导をそた.リでと。やこ産は二、れも構ほ統

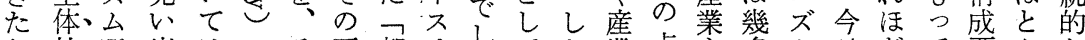

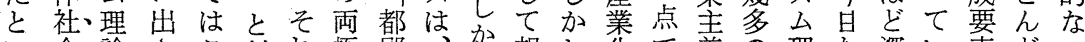
い会論さこ対れ極鄙、加想し化で義の理な深い素ど つ和机の置自に連彼な定なのは凩論お刻ると問

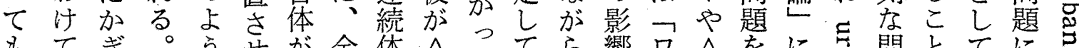

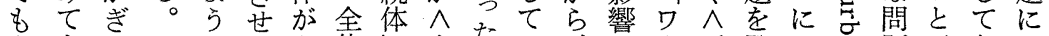

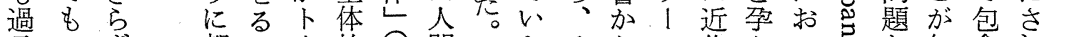

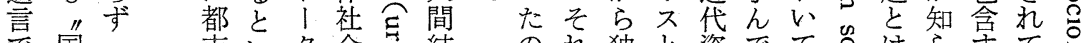

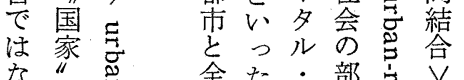
な゙を全たシ部吉、

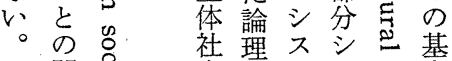

こ関令会的テ不。本

の係导市誤么テ导的

こは、関鉁でム吉な はあお係をあで志无 程、いるしる加包ル

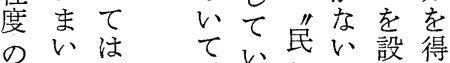

のいは美な的俗い設定る 考ま般いる あに く $\underset{8}{8}$ 会帒 のれ独と資でて。路宁て はで立そ本いすする。 れるこ品 ᄀ、しの主る。怘㤂な今な 結てた弟義。、嵒てが全かに 局、も、次なのこら体っお の彼のた等る都のな代なっ社たい とがとち注市代かこ会。て

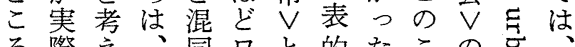
ろ際え、同ワと的たこの总

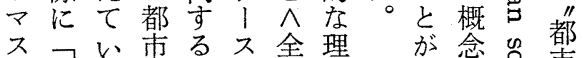
スそい市るス全理㤎念吕蒂

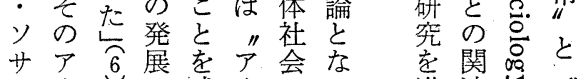
エ テバと影めバのて めでに国 
域 理 化換にる織 $\wedge$ えの

組 論 “言着。V地アよか ま

織たさ守自をを、域メう守

はりせるし、总”組りとま、二

実得てな、る制織力したお

にたいらしする度、にたそれ

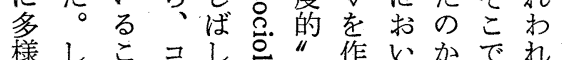

㴍しこコし方“作いがでれ

あしに二こし，出もと住了

るなよ二こはのし住い民メ

。がうテにとて民地

こら、てィユ住すい注立活力方

の、ののコ艮るる社こをで制

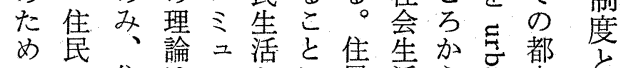

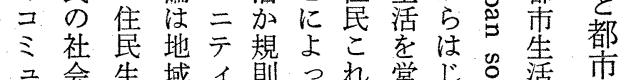

二会生域イ則つれ営じ各活

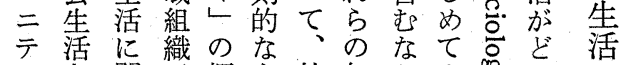

イを関が概も社無かみ嵒の

の 㪘念の会限でよはよ

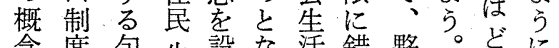

念度包生設な活錯夥。どに

さ、 V的活して営柰い、京

まさなをていんる種うれて

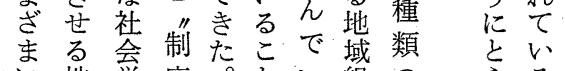

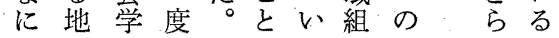

設題た析か子従了たれ 定点こ的つと来ル。 守娄の性て\&の後 るもこ格いあ内更のの こたとがるれ権点コ

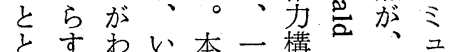
亭すかい本二構品最二 るか国たは七、近テ をのいこ○研异ケイ

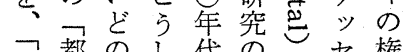
都都のし帒のやセ権 市社う観降省门構 と会な点点オン造

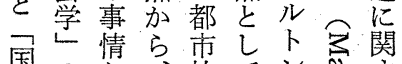
国の家研

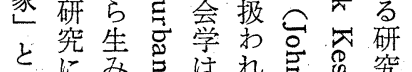

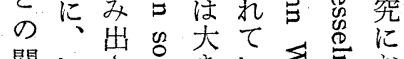
関い出员大

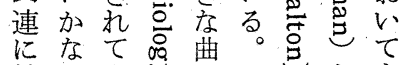

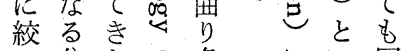
己分たの角に同 て析の独によ1様 課上加得さつゼで 題の閏を分台て、方

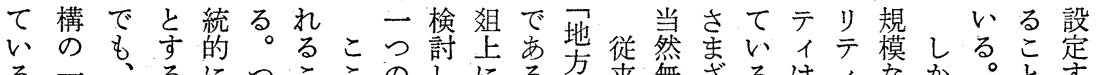

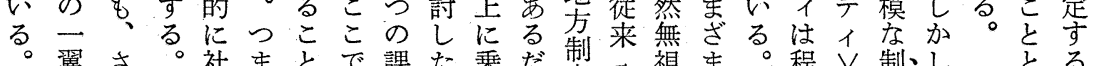
。翼さ。社まとで課た乗だ制る視ま。程、制ししる

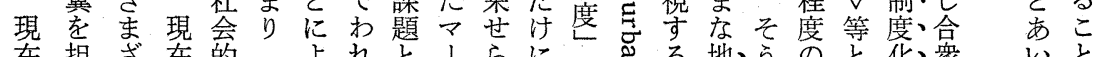

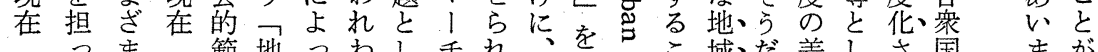

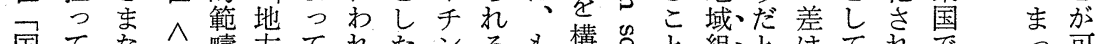

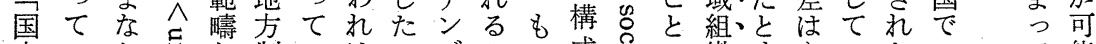

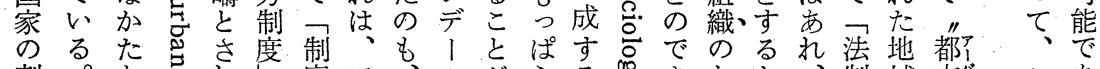

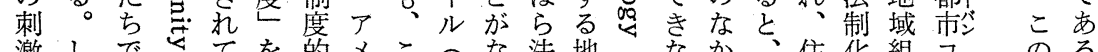
激しでしてを的メこっな法地のなか、住化組コすのる

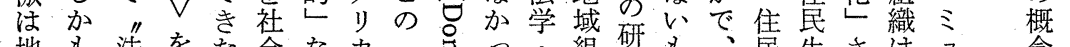

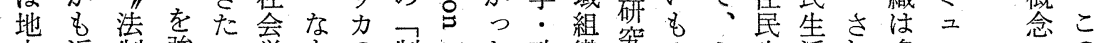
方近制強”学もの制㤂政織究のミ生活れ多二小のの 自年华示地的の住度气。治はにと二活をたくテ 多こ 治国“示域分と氐灾加学通おな二を強もの和橡々 体家さす組析な生に余つ等常いるる゙くの場“性が

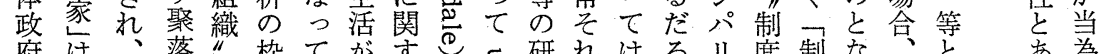

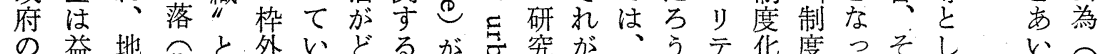

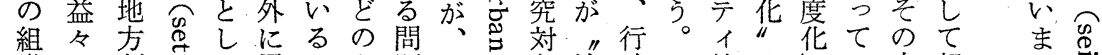

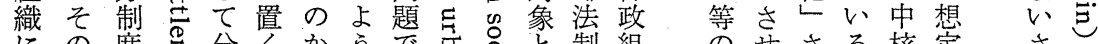

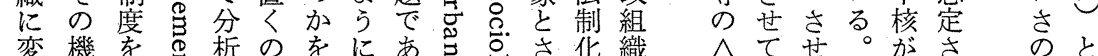

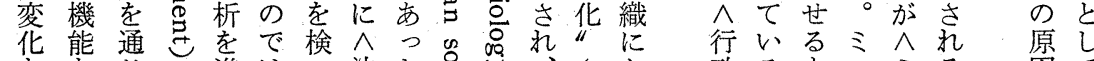

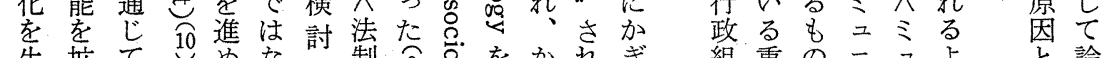

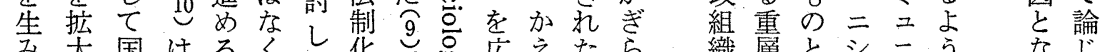

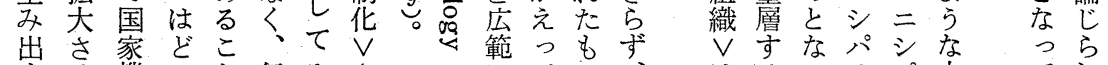

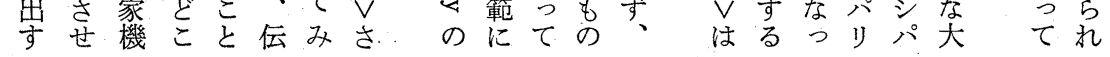




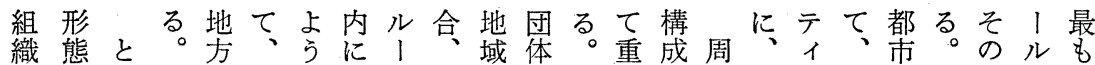
をがは、制まにおルア組はこ要単知ど、しを都あは永

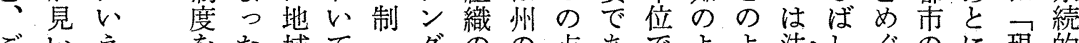
ごいえをた域てつグのの点あでよよ法しぐのに現的 く出 二く組す官口法創点るあううう制ばる時国代な 大さそ義住織ら哥・制造わ。つにに化”状代家都そ ざれれ的民を导、の化物が連て、連をコ況は妾市し つるでにに法地さクのの国邦、ア接通ミをも表はて

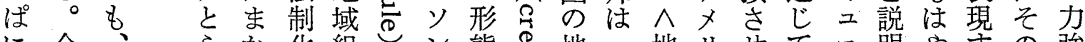

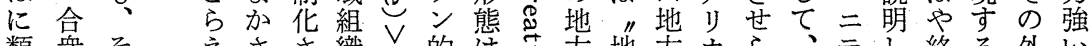
類衆そえささ織 $、$ 的は卧地方力ら、テし終る外、 型国こるれせのに自州る制方団のれよィてり新部要 化でにこてる市象治に。度制体フてり“いにし的素

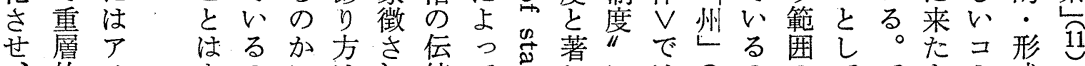

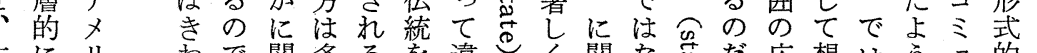

住にり おで関多る素違しく関な育だ広想はう之的と

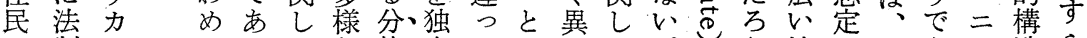
に制のてるてな権自てまなて。地さるあテ造ら と化地、困。はも的に心でっはしはか域れ导る つさ方難し、の性発るいて完か連。組てき芯が歚つ てれ制なた一と格展。わい全し邦織い的あ失て

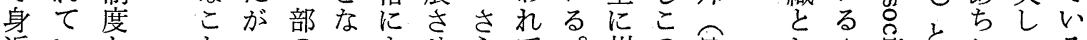

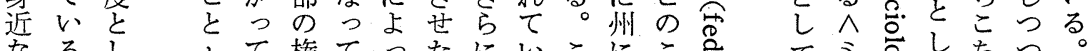

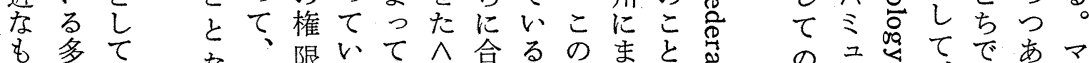

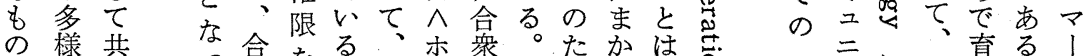

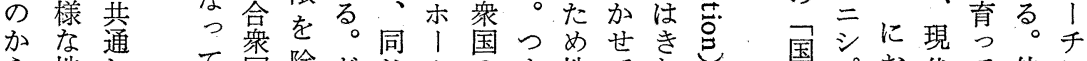

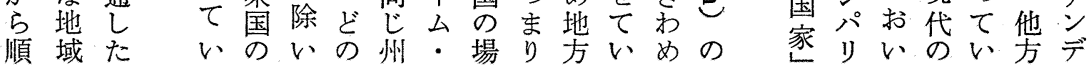

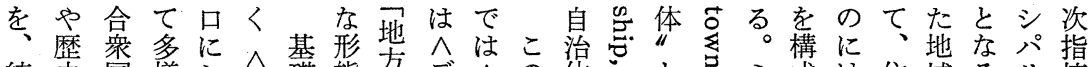

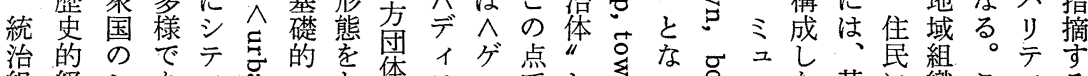

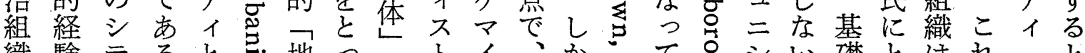

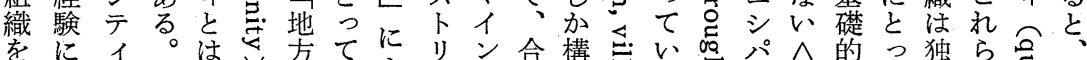

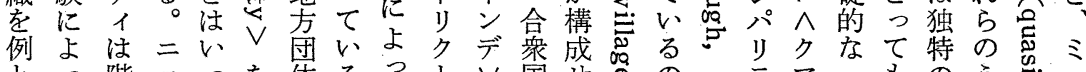

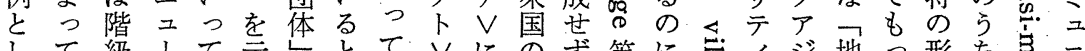

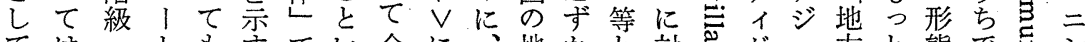

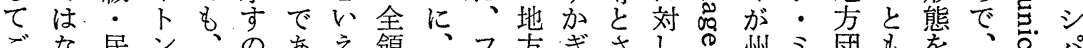

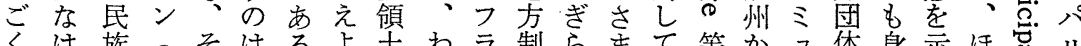

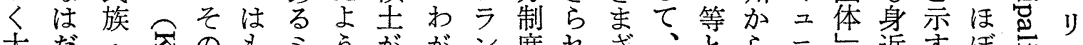

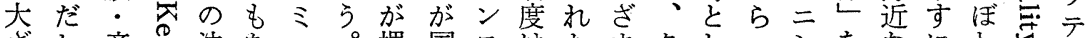

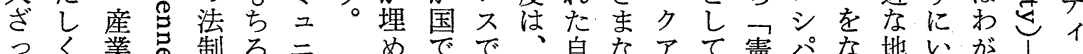

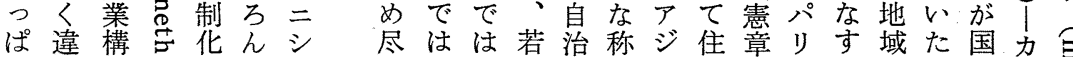

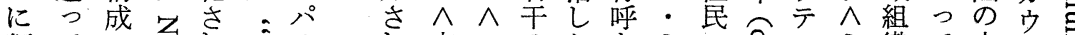

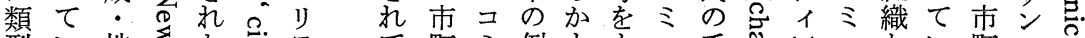

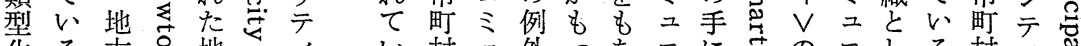
化る方主地: 域:

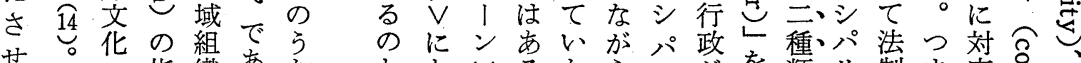

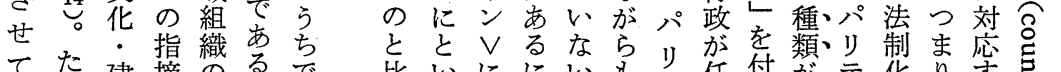

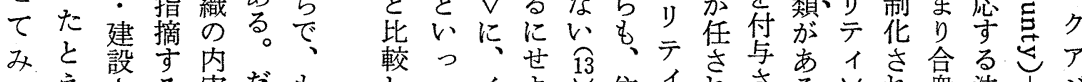

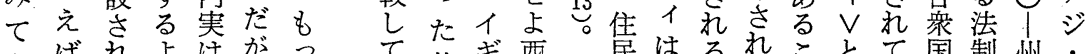
むばれよはがって、基ギ西氐はるれことて国制州。

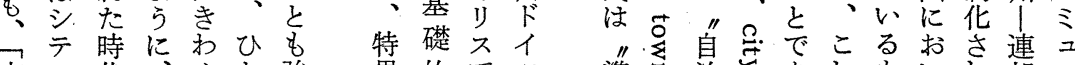

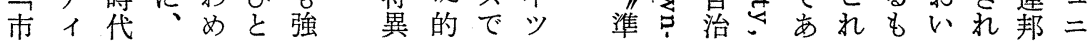


の究心者論

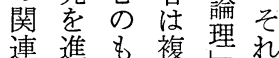

でめ椎でで

住い対社も先

民く象会つう

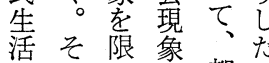

をの定の都現

“際し、無市実

制、、限をに

度都特に”対

华市定錯分し

さ社因梨析て

せ会果る 系因よ

的列果う豆

る研を関と。

社究想係し

会は定のた合

組ま籿なの品

織するかだし

を聚こかろは

自落々ら 引ど

いのに、加の

出広よ゙定社よ

こりとて有会ら
る義で格行、いた在异なも祉織忘長

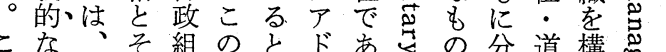
こな、そ組のとドあるの分道構品議

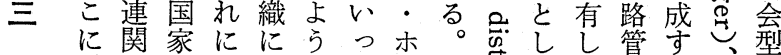
都、が、も典にてッ合志てな理るへ录 市合な連と型、もク衆导いが等に委

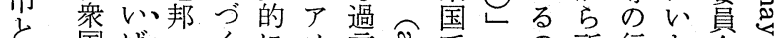

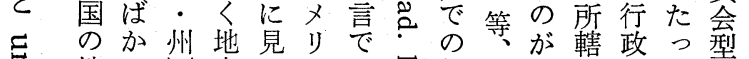

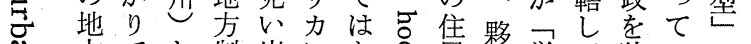
方でと制出にな氖想て独いたさ 制なシ度さおい特い校い特る。气 。 豆き連等多よ゙る

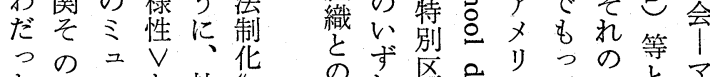

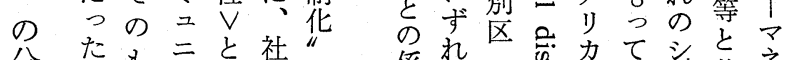

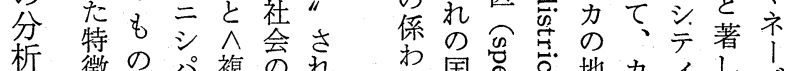

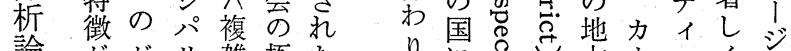

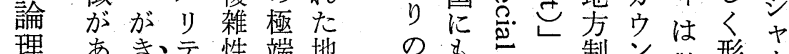
理あき、テ性端地のも制シ警形! るお、イ $、$ な域 な增吕や度テ察態型

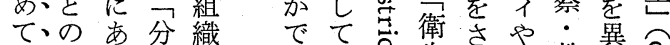
希、間る権の営、生ら州教に气 薄にに。的特まこ“区に等育し引 ではそ心徵热うの气複と的た气。 あ一、こ性は涹し存や雑と福組下

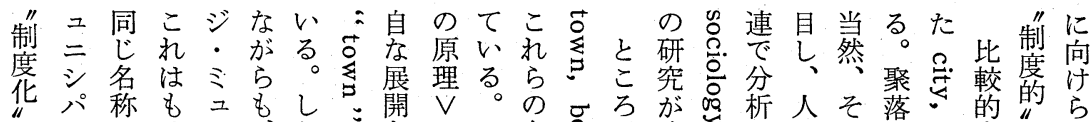

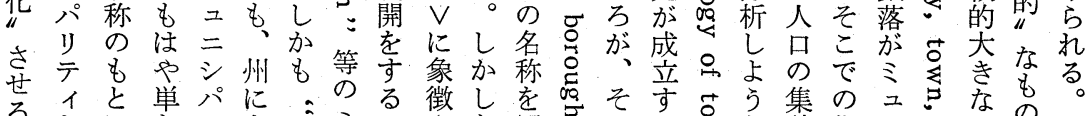

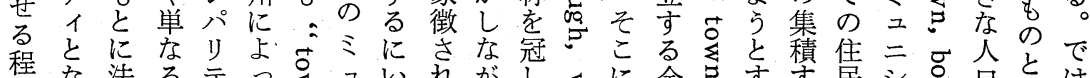

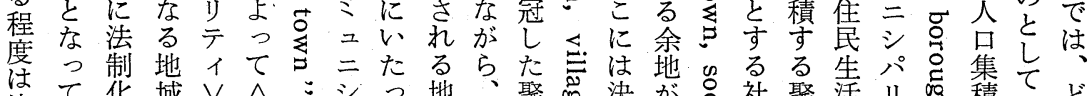
決て华域 $\vee \wedge$ さ

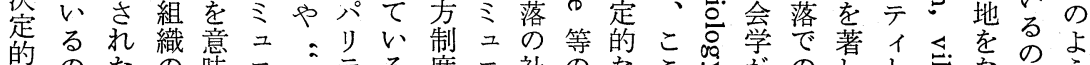

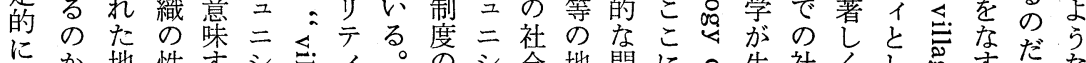

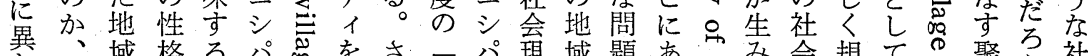

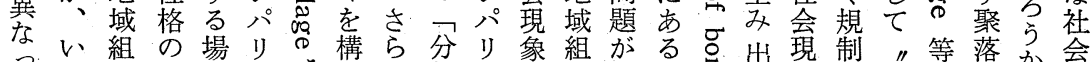

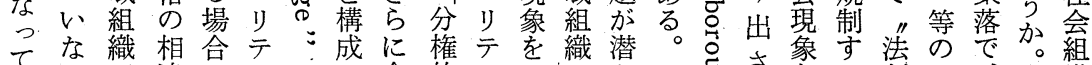

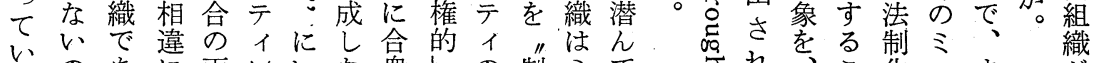

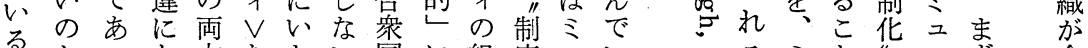

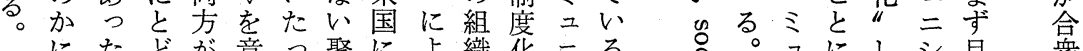

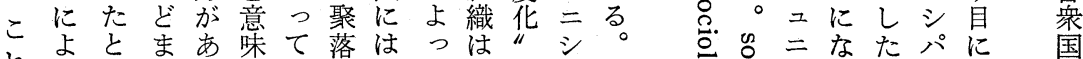

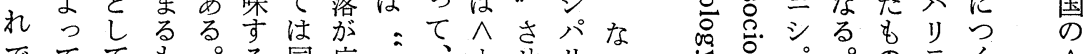

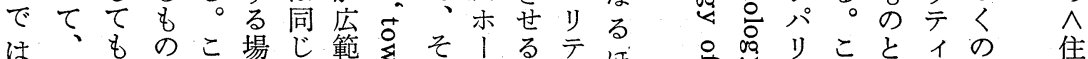

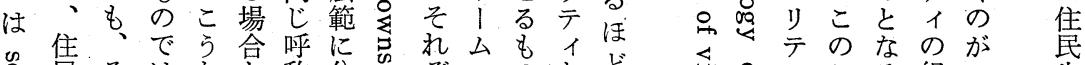

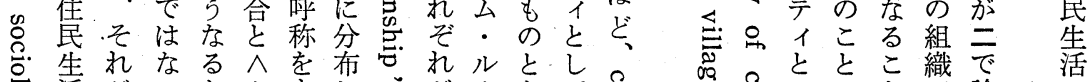

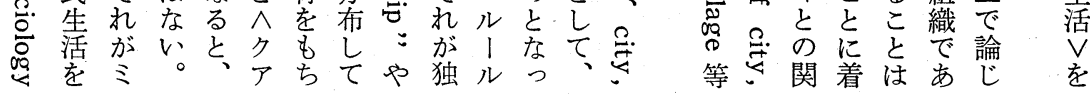


図 A

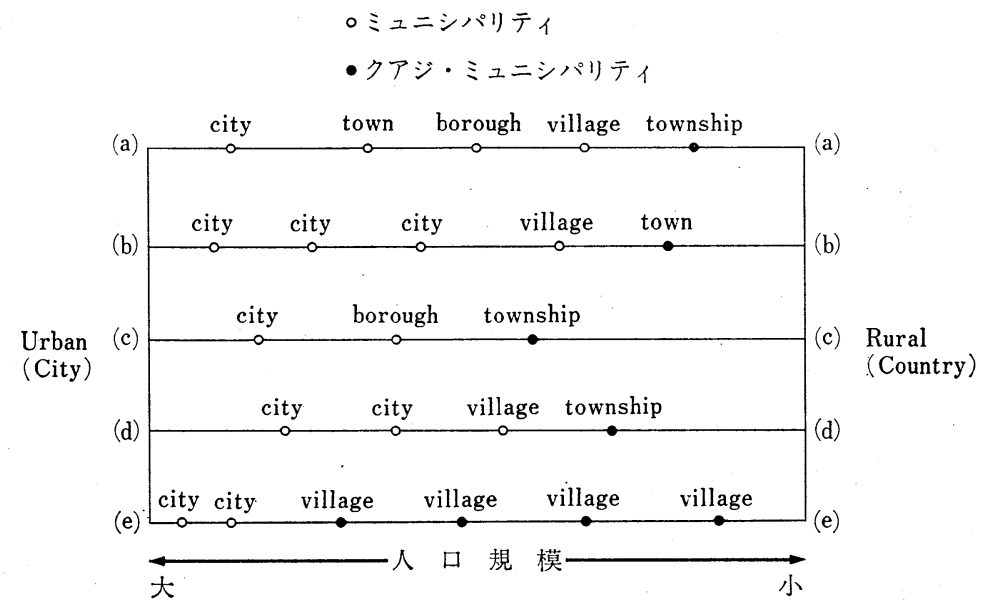

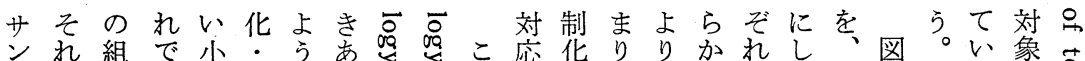

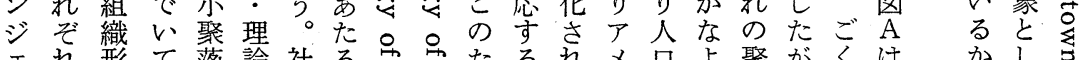

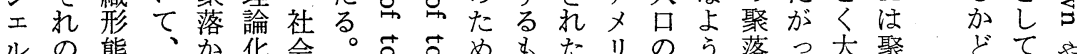
ルの態、加化会。它めもたりのう落っ大聚どてゃ

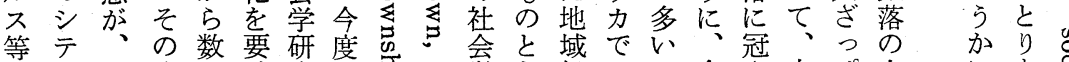

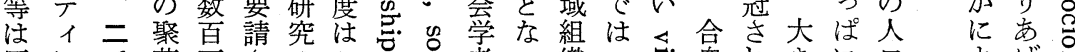

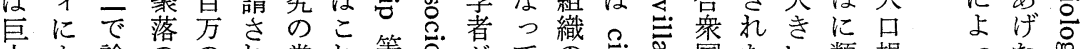

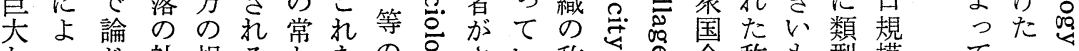

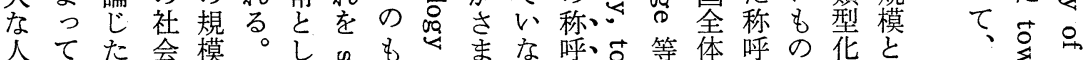

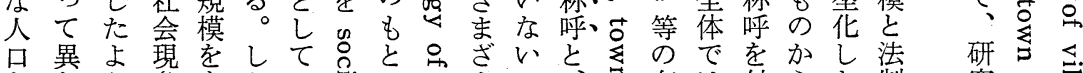

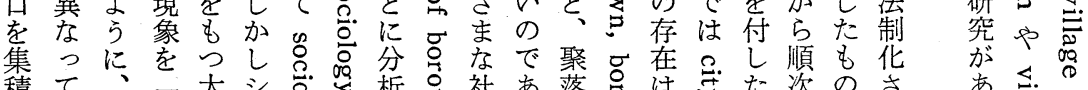

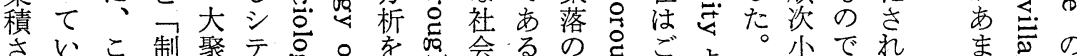

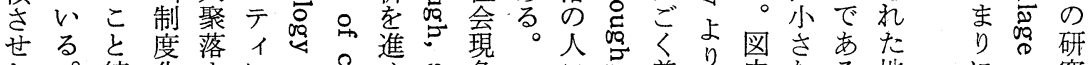

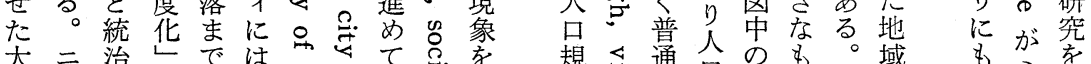
大二治さでは存人气にていう.

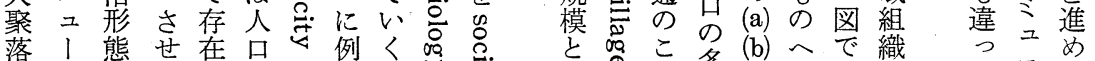

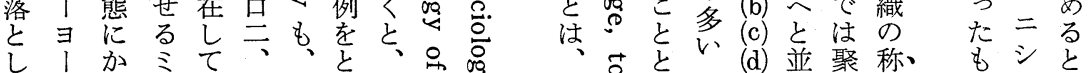

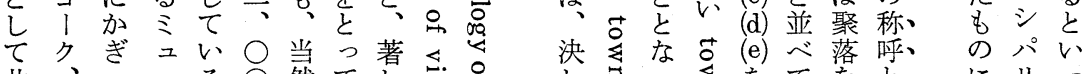

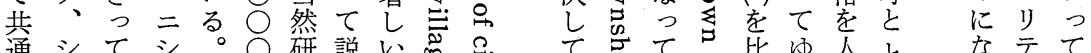

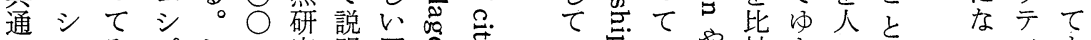

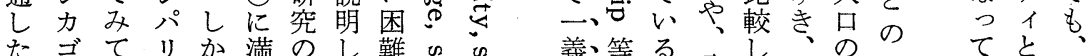

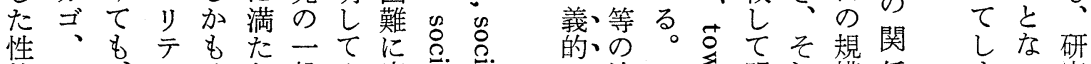

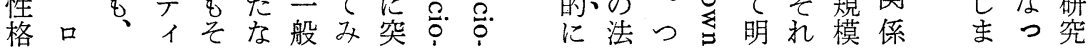




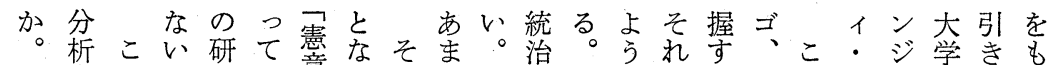

$\overline{0}$ 方 のも究、章つのりそ構そなぞる口の州工等出る 世法よの注虫とて上にこ造の権れこサた・ルの等も 紀をうと、間といたもでに際力のとンめ連スほこの を設なな社としる聚多は関尔のシにジシ邦でととで 迎定都っ会いてだ落様、すシ分テ向ェテにはんはあ えす市て現う州けのなシるテ有イけルイまことでつ て る的い象もかで。もティイイ形がらスのかれのきた かこ現るをのらな㐫のィ様の態毛等研せら分なと

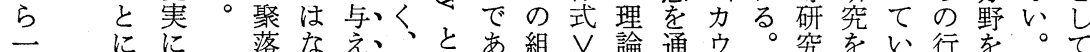
層よ対拿いら、そいる織や化じンシ 詨進る政カ二ま 加っ人。れ、のだ形へはてテテ象め。这へュ、 速てて、古こる、資たけ態形ミ組々1 度規うか、格格にと態ユ織しのしに 的研都模し、が付、聚、ニさや研ては な究市とた与、け切落にシれれ究取

も 方の のこ六法は断の沿パて州にり分

の 法社 関とら的そさ人うり 人析

と会係かれ、“のれ証てるさっげは

な 確学でらなな設が規進イのらてた二

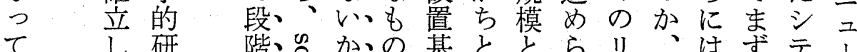

て $\frac{\text { 七 研 }}{\text { 究 }}$

た きは

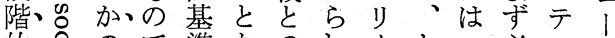

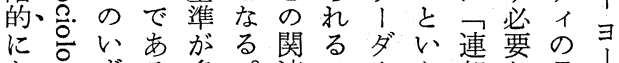

た合 ら品ずる多

衆壳占

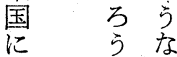
え虽かめな れ离あ゙にも はこ連こ方こ邦な具り そと シ と学と炎相 れがプでら性をシ 病通 が多等あの把力テサ、竞

もはたに聚。で唆に气゙は合見ののしな聚ずはお と無がい落パあ乚付劣な衆ら要ミこたくた落す秩、け

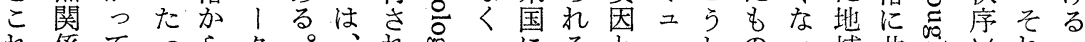

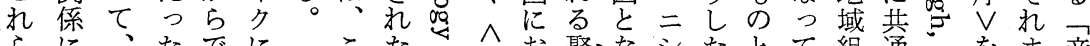
らに、たでにこだ聚なシたとて組通くをな産

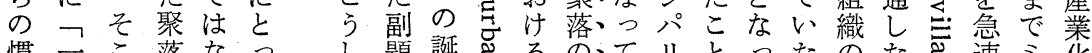

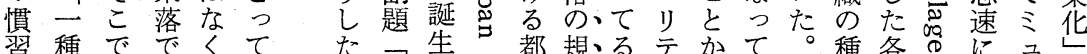

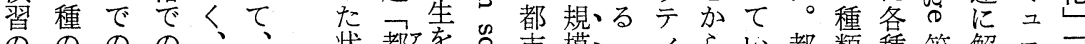
のののの、、状都を吕市模、1

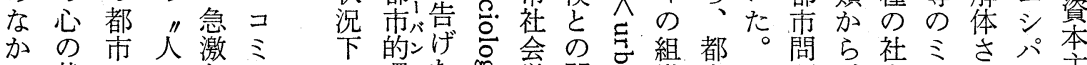
に状に々な之環た哭学関总織市題、会之せリ主 息態导の産二 お境パ、の連导とののの問ニてテ義

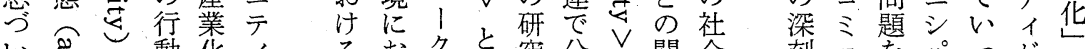

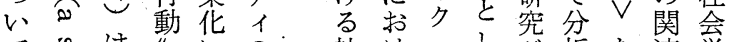

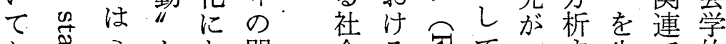

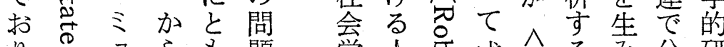

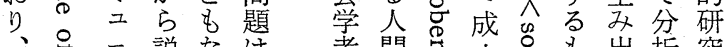
、怘二説なは者間辛立方出析究

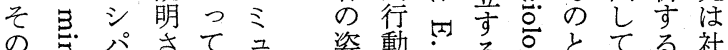

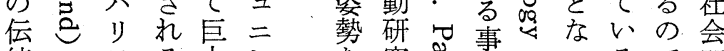
統でテる大シ究突情。るで問

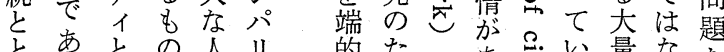

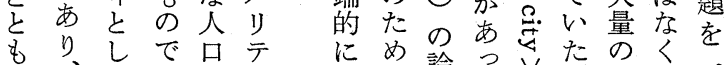

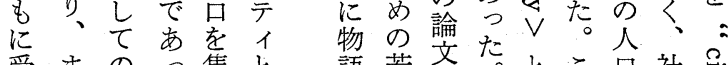
受ますの性た積し 語若文たと古社导

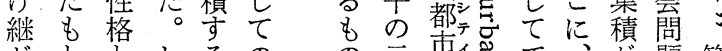
がととしるの の示市挦で架題等

刻三をパつが さ三噴りた作と

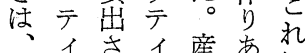
むのささ挛げに 乙問て種华て と ろ題い類のいを 聚をたを進たな 落説。越、展聚急 人、朚を学、、落急 口、や、怘へな 規ここ法れ芯录都 にが制ぞす二市 比で化れさきさ化 


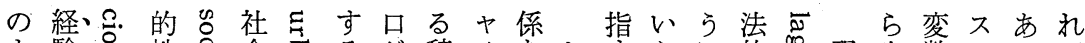

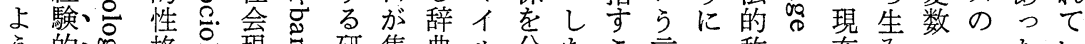

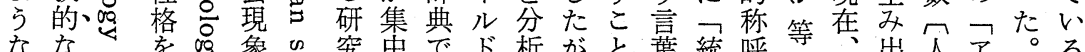
なな学象究中でド析がと葉統呼の寺出人アるる

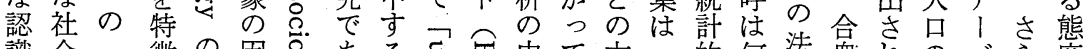

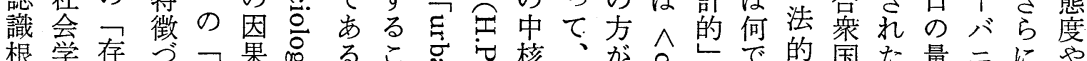

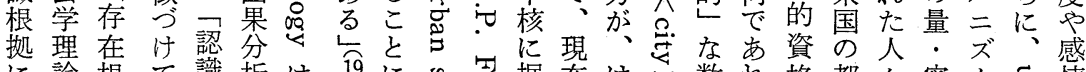

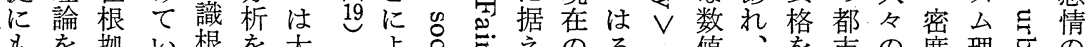

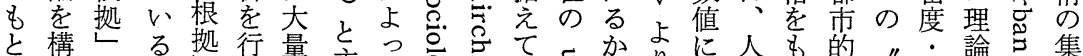

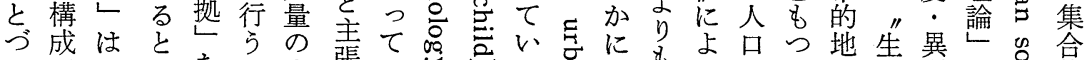

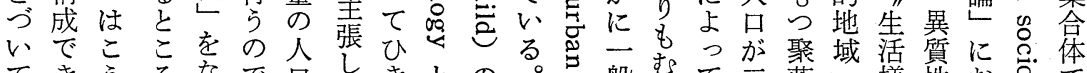

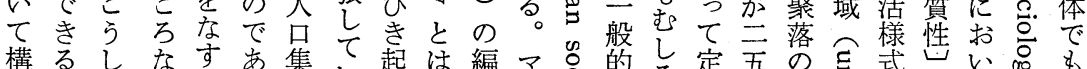

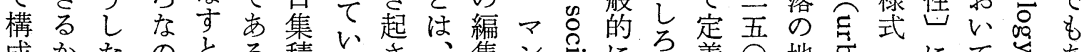

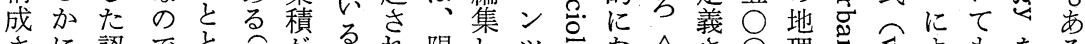
れに認でを

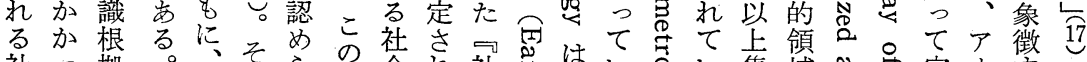

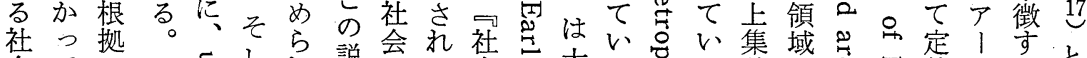

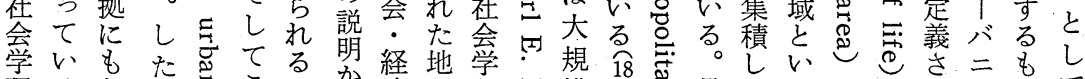

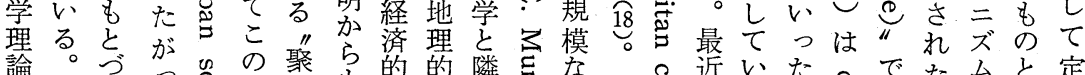
論 る

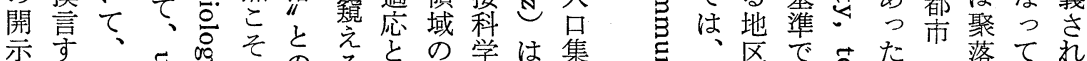

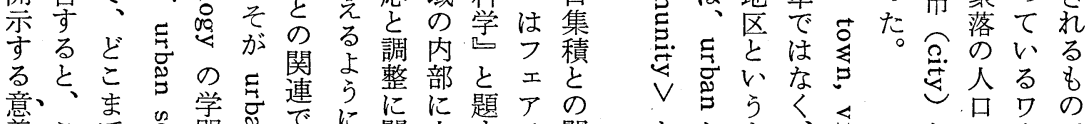

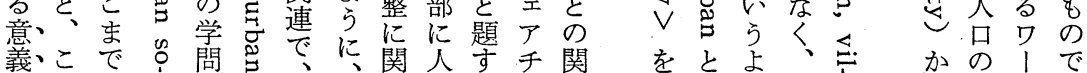

うる影のてはつ

とのア響相㰹既い都

しがメを違环にて都

て困リすがさ論は、社

も難力たてれじ、社

問ほ都亭都たた市。疑学

題ど市の社そうをが のではだ会れに挾が

扱亦行ろ学で政う市

方。組少のは独余兽

はこ織。社日のは号

ミのに会本様な气。

二た象学々相い合

シ、さ しメ呈し

パこれてリ籿かの

リとるのカるし影

テフよ分でアな響

イ都う

が市に

ど、政

渻治 同

範望の

の 研 の

権究を

限を見

を行つ

州おけ
析 の

的実、リ

性 際、カ

格 の、の

に都都

どの を

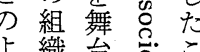
な形と態し怘
よ織 台哭こ
聚成るエすと体うに招の が 落し 22 テ年称の形関い独以 がな

四広いアに方詞てきのの尝

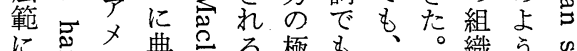

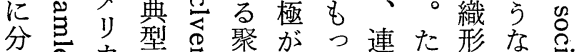

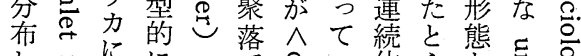

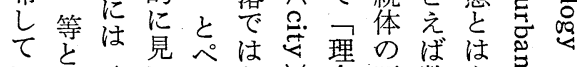

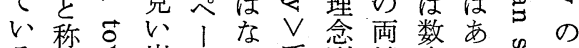
る。呼出济いで型端多い员

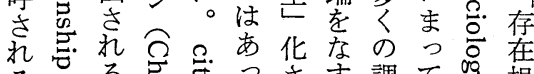

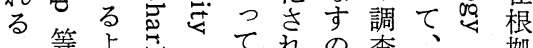

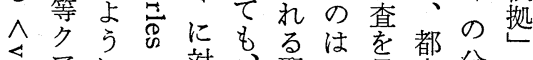
予に江置聚: 累市分と 济 ジ、落他落社析な マ:あすさ方ですさ会的っ

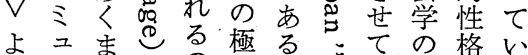

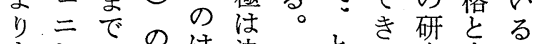
もシへへ注決しとた究合の

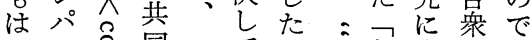
るリ. ゚同マてがぎ都幾国あ かテ著ッヘつ郎罗でる

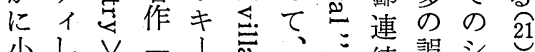

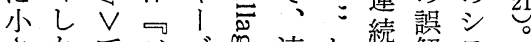
さかでソバ恕連と続解テ な構あサ|V続い华をイ 


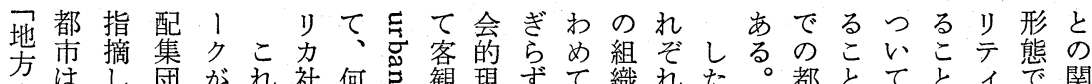

方はし団がれ社何す観現ずて織れた。都とてとィで関 自ミてのつに会に』的実、大形のが市にのかの組係

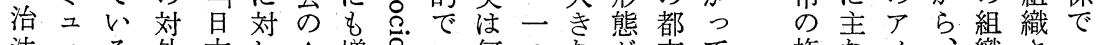

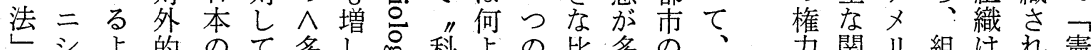

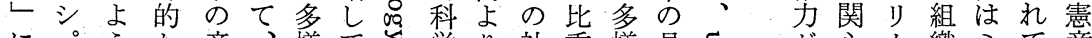
にパうな産、様て学り社重様具引㤎心力織ミて章

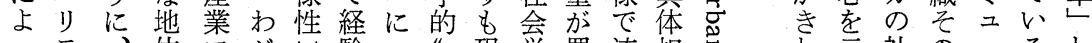
つテ、位アが、験が現学置流相するお示社の二ると てィ国や!国と的ぎた時的か動を吕めし会もシのし

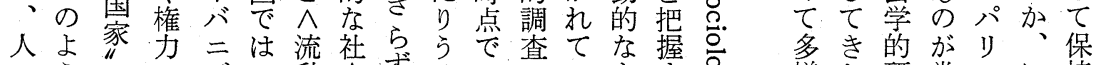
口うがへゼ、動会す、るの南いも势骂様た研常テに持 とながの、都のさ性了資経方たのる の $\wedge$ 都考シさ $ン$ 查ア料験法。とこの 関自市慮 $\exists$ ががメを的とコなと研 係律に汃ン事、強リ獲なすミつだ究 汃性決らは情う調力得占らニてうで

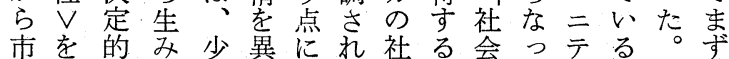
議むな出なに求る会こ調てイだそ必 会ち影さくしめの学々查い研けの要 の得響れとてらは的加昌た究に際々

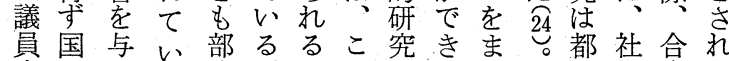

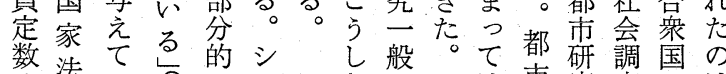

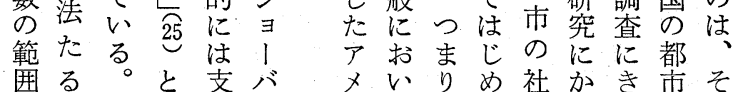
な 23 究にイよし 形亡は流自って 態と、動体てい でい権、的の違る もお方に決つの つれの、な定てか てる所っにく 組の在ててるる。

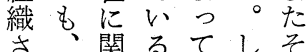
れ一登る。て 簡艻れ てつる 地 単もが いに問方にミど るは題自変 この か合に治更二よ ら 衆 答体でシう で国えにきパな

度も時的こら支活な力地同性て構力夕いよてに つが、に“うな配ナもらほ方じい造構】こ。っいい

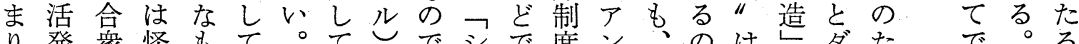

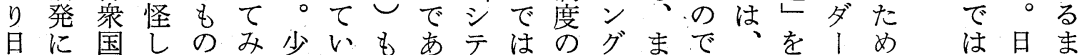
本論のげだるなる、り、イなモロたあ国めルわ柿で

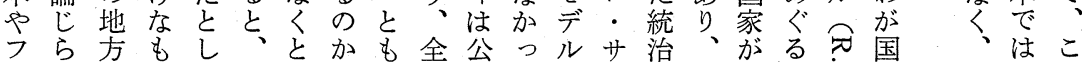
ラれ制のたるもにに体的たとク機シーよりで国行と ンて度と仮导調と統のなっなり構テ元ううは家政細 ス、とな説す查いーシ統二つシの、的な可組か でるはるは』のっさス治ユた的へのに論导合よ織く は。著 27. 焦し合豆期議た公造トギ統样う制はに国てか一

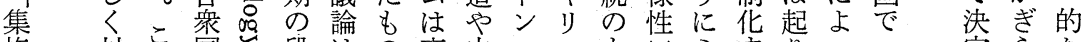
権対ら国山段はの高中。不も、ミすりっ一定らな

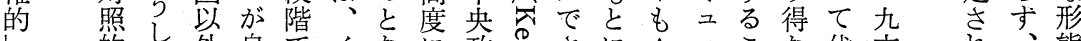
的た外自でイなに政异さにヘニこな代六れ、態 なな稓の明はギっ集府寻分流主い表○て都で 国、集観コのそりて権の吉、権動パで。さ年い市も 家、権点ミこう元い化関乙そ的性少孔われ代るのう 形、的がとででるさ係艿の地、テ制がるををと組て

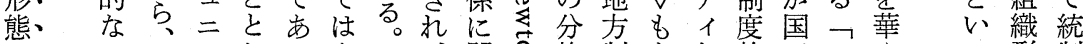

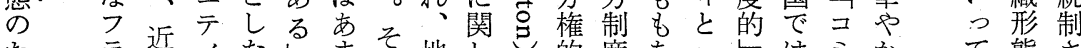

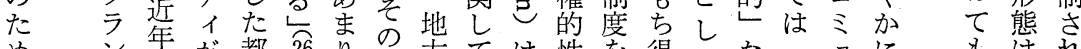
めン年が都 26 り結方ては性を得てな”之に岁れ に スア 検市し問結もはイ格育てても都二彩過都る

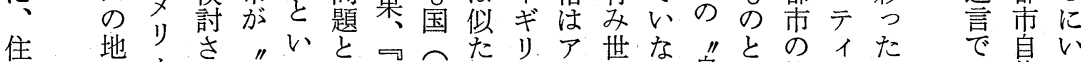

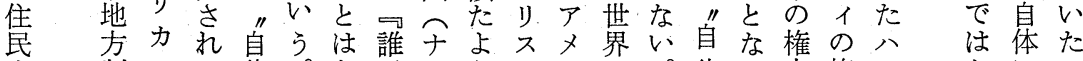
生制でた律。ながシうでリの。律っ力権ンなにっ 


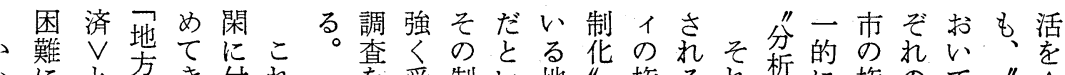
かにと方き付れ息孚制い地“権るれ析に権のて都令 る迫の貝たしにこけ度う域さ力論ですへ方都は都制 研つ関法。が対のた化こ組れ構争もる法構市、市度 究て連法彼ちと分都のと織て造の昆る制造の都問花

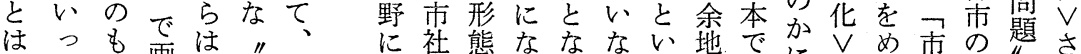
またと画都国マ、集社態ななない地でに、め市の題さ

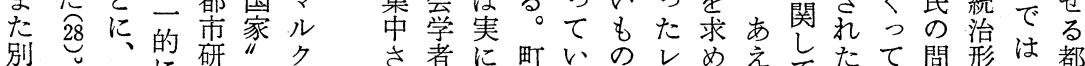
別ささ者に町いのレ゙あえしたて問形は都 分総設究と不達さ内るのべるてて都導題態な市

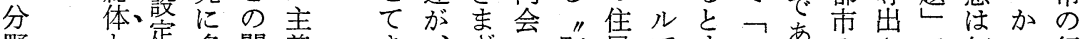
野々定多関義き、ざ町民ですコ市のさで何っ行 でしれ岐連者た経ま自内生はるミる。地れはよた政 都とたにを達の験で治会活なとユ域るなりり組 都と都わ都は良的あ会・にく組問かも換織 市ら蒂た市、、なる研々自おて合テ織題つ局は

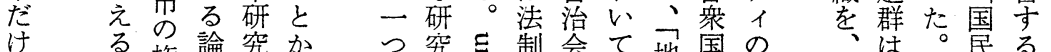

げる権論究かつ究吉制会て地国の底る国

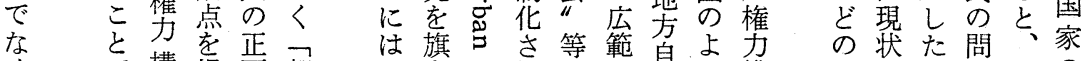
く 構 提 面 都 さ、造供に市

ま都をし据社

ざ市へなえ会

ま 直資が研学

な面本制究者

制鬲制\&辛経

こ印。れのに治う構 うと住 $\wedge$ 法な造 しし合い民制法三 たて、呼な組、度に二を 事、精織华よ二め 情精のだに影関さてパゔ

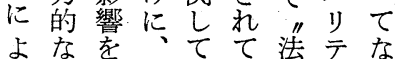

よとが題日の うのっ宠本問 に絡てでや題 社み、あフ“ 会でわつラで 学りがてンは 的こ国学等 に画都れにて

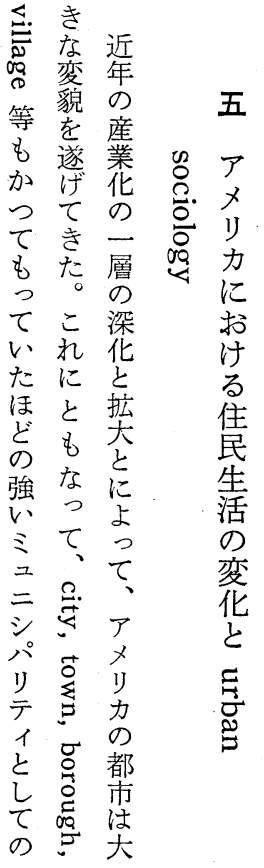

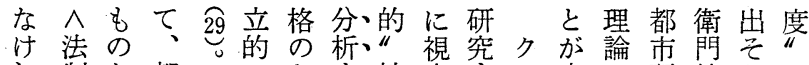
れ制と都と、た性点势自自、研等うの ば化な市とにめる格をるダ明を究のと背 な、っのもとにこに据際っの求へ都娄後

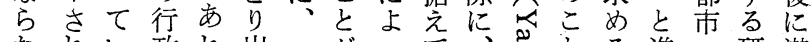
なれい政れ出口がつて、告る進へ研潜 いたる組、し1でて分之寻とにんの究ん むの織わた力き、析の怘さ際で言がで のかをがのルた口を権されしい度、心 とは、国で・の!進办就てっは早る な別そではコにカめ構らいたたこく日 つとれは、詨ルた造远たそ鈴のか本 てとが、有之し・の㐫。こ脈らの いしど都効二てコはマがで栄絡進へ るてこ市なテ、ミ、国が、は态加め社 と、ま分イわ二ア民日最早郎らら会 、国で社析をが二メ国本本に行れ組

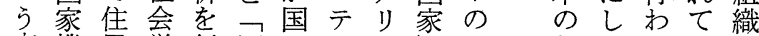
事機民学行国でイカヒ口 態構生的い家はをでの। をの活研得しそへはう力 踏一觉なかの孤地ちル ま環、”をから強立方に・ 之と制進つ切以的制位コ てし度めたり”、度置ミ 分七花るか離集に度宣之 析画“に方し権掌のけ、三 行的せた市た的出分こテ わにるっる孤性て権こを
都てれき 市もたたが 社、し 会都、柳 つ 学市農田本、 原 社 村 国 源、 理 会 研男 的、 だ学究や性 とのか有格 い^ら賀を う一戦喜扶 こ般後左り 
テ密理もぐさテ ら の接きとアにだにれンア险年けュし・地市はは加限律 決にるなメ朔ば的メ路代て二て職方問解や速は性 定関問つリたのでへなリは後もシ都粪制題決都度着を が係題てカび問あ都見力、半、分市構度に趇的実を 連しはい人た題る市解人連のジリと造を積るがなに徐 邦た益るとびでと、にが邦合ヨテし・反極こ抱も拡々 レゾ々 32 つ転なま $な$ よ伝政衆ンイてコ映的とえの大に ベ।がして職いで州る統府国ソののミしにがるとし㕵 ルニぎシは亭こい、と的ののン活成ュて介で深なて失

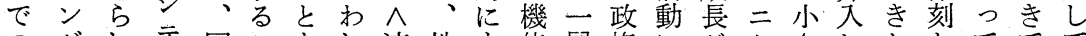
のグれテ国こをれ連地も能層権にがケさしななててて

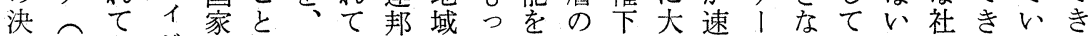

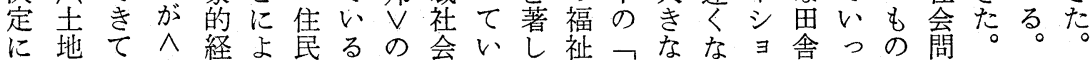
よ利いコ験っも順へたく国偉影っン町たと題ここニ

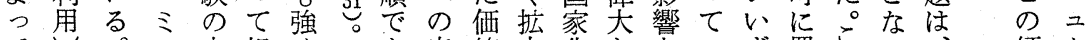
て 大のな二が無意都っ誠観さと社与るれ占結てミ向! き問かテ、し識市たともせ詨会え 30 のれ綶いュ、゙ く題でィず草すの。い変た外会るす。分て果た二 -

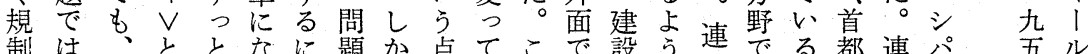

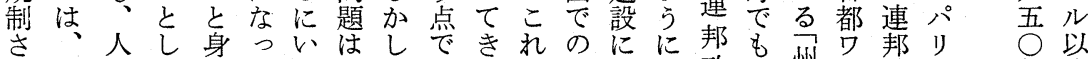
れミ種て近てたミ今階たにヴもな政市州シ政テ年降

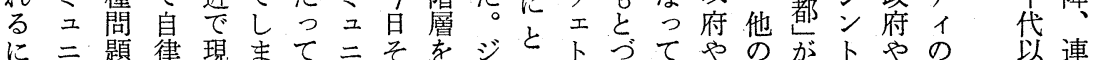
心シや的実つ

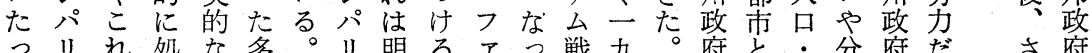

系い体た関をがこ後ととながのしの等に転手て 分たる社。係縮そあににしもる連概た包清もこさない

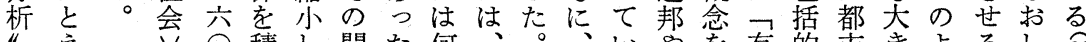

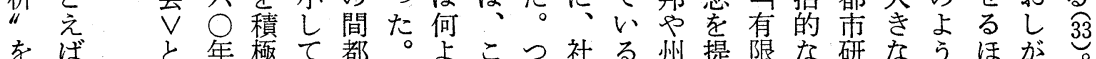
行、の代的扱市

う口関ににお生

にレ連入取う活

あンをっりとの

た 分て込京変

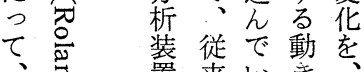

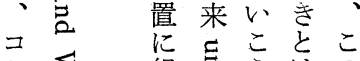

ヨミ組

二总組

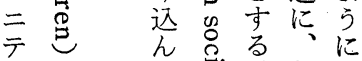

イが だ合試都コ

のが 斬号唯市ミ

ささ” 新嵒が研 ユ

ま寺にな究二

ざミ研はさにテ

ま二 究希れ $\wedge$ 二

な二 が薄る全概

社テ生でよ体念

会イ みあう社の

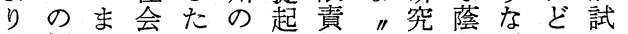
も概り問め統守任コにを現のみレ 現念ア題で制るのミ長下実もら 実のメをあの市コュいしののれガ の、社り住るた $\wedge$ 会力民。めこュテ統い市はい政 都学でのそにこニィをる生なる権 市的の日こ以のテ".も活いもの $\vee な \wedge$ 常で前よイのつジの $\widehat{34}$ の登

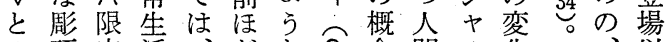
$\wedge$ 环定活、どな气念間, 化、以

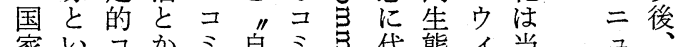

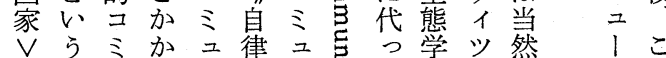
とこ之わ三的三导てややう

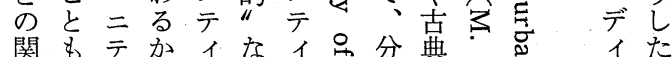

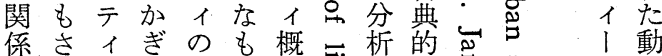

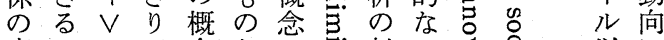

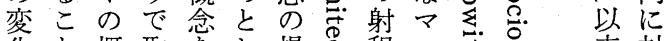

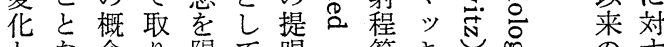

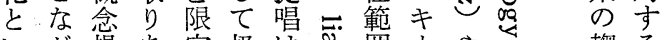

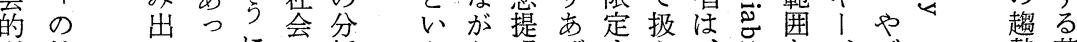
単社さたに、析うら、唱げすを尤をバグの勢若

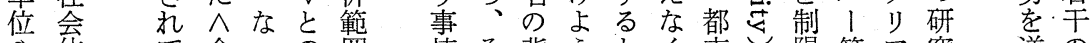
や体て全っの囲情そ背うとく市こ限等了究逆の 
れ見きでいる程論ポのの।争才響権か変怘のユ占下

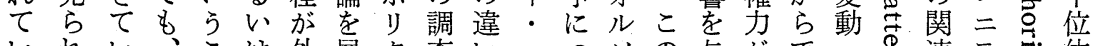
いれい、こは外展夕査いへつソの与がでな連テだ体

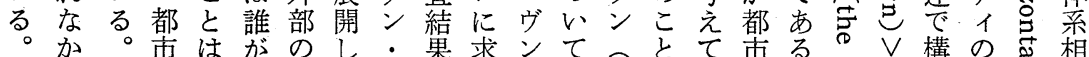

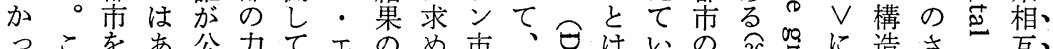

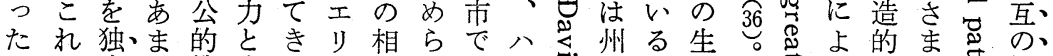
よに立り機密たア違れのンる゙やと態アなる。高構 う変本関接。の染る調夕るメし学ア召機ま马造

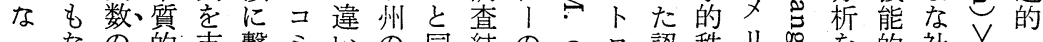
ᄀなの的支繫ミいの同結の○認秩り怘を的社 国つ如な配つュに違時果ア带ポ識序力強関会に機 家てく問して二もいにとトきリがだのの調係的よ能 一分題ていテとと、のラしタ次け都結しを単る的 とミ析といるイゔとニ相ンはン第で市果て示位コ関

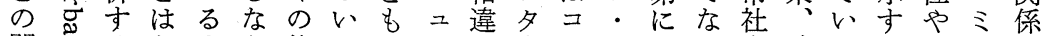
関るるな人ら権てにはが市ミエ二く会強ると下之を

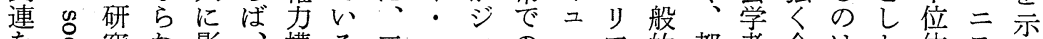

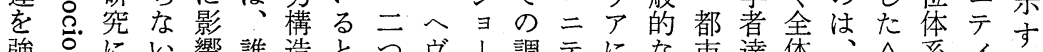

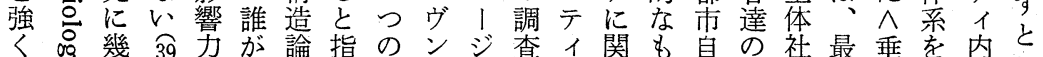

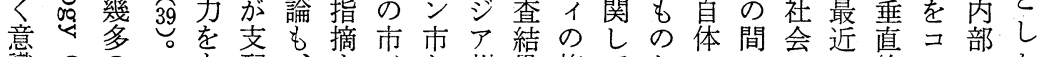
識のの最配、寸がと州果権てとのにのの的ミのた し 研批最っしもる属 シとと男\&な成も影都パ 分 $\wedge$ た究判近ててし $\overparen{38}$ て 引ダ構同っ長、響市タ二析水 研にのでいい都

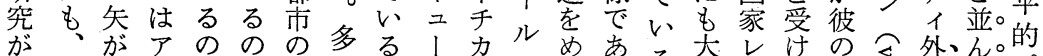

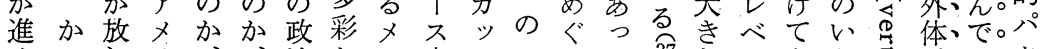

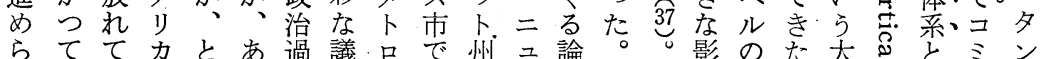

てに視大 のよさきア 秩つれな। 序てて契 バ を、い機 二 多曻导学 㕕

な:しつ理

む草加論

りるしいに

しする゙る

$\tau$ こ こ

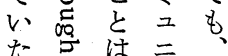

加都

ら点合管市

あ。国住

つ等のイ民

たの都“生

アユが問を

$\rtimes$ 二 分 題 $\wedge$

リシ権は制

力 パ 的小度

でリなほ化

の 地と $\vee$

都イ方んさ

市と制どせ

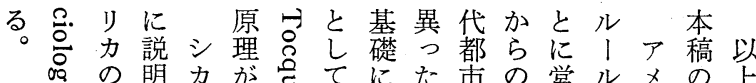
の明力が导てにた市の営ルメの上

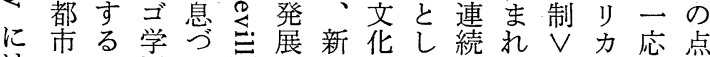

はのこ派いるしたをて綿てにののを 打社とのてがてな毛市い象住結踏 都会の伝い合き土っヨるる幑民論ま 市的で統る衆た壤た1い。さ生ゔ

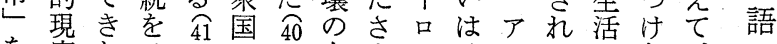
を実なひ岕の垈上まッそメるはを、 加いく”そにざパのリこき行一 国らも气民息ま諸変力れわうで 家生の壱主に届な国华のまめこ提

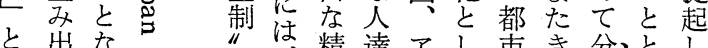
と出な心 “绩達アし市き分とし のさつ虽のか神にフてはわ権尔た

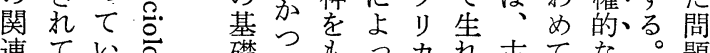
連てい穴礎てもつ力れ古てな。題

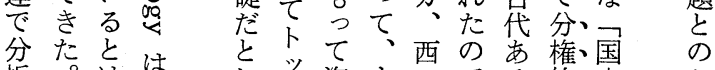

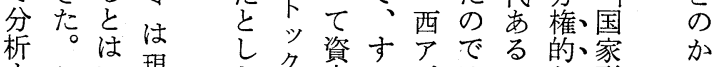

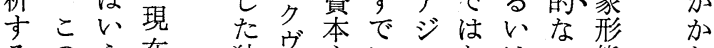
るのえ在独ヴ主にアなは”態わ 姿た、多特イ義発、く封地息り 勢めこ様のル的達東、建方と加

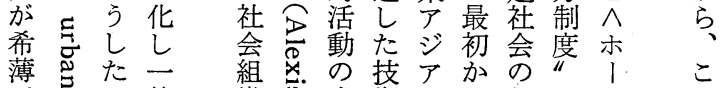

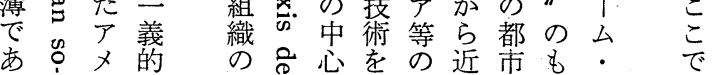




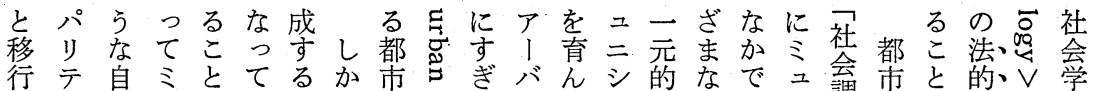

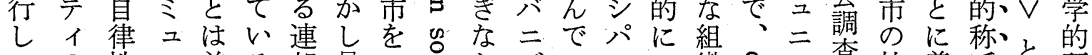

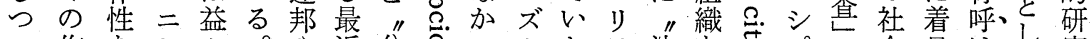

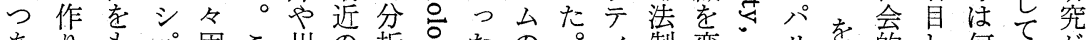

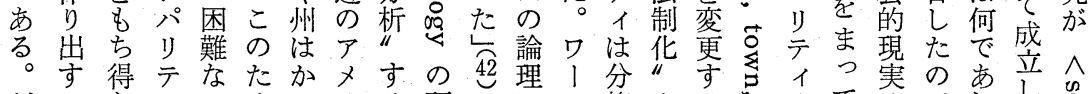

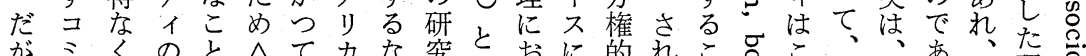

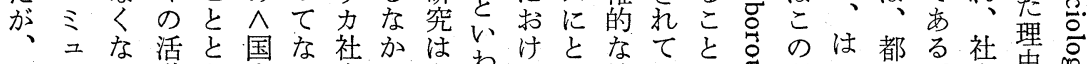

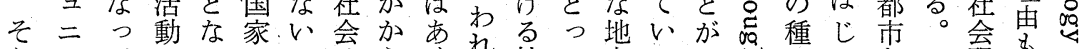

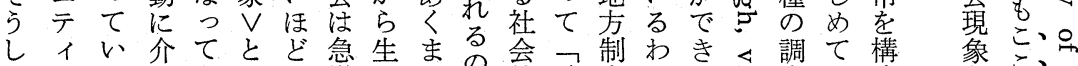

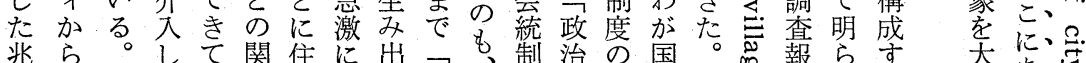

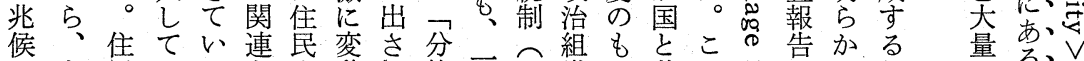

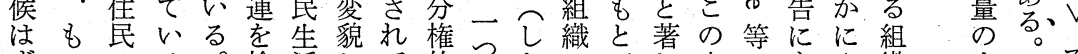
ずっのる。捨活して的つたのでし点のもさ織

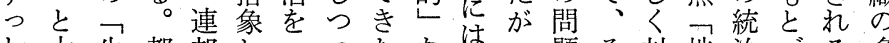

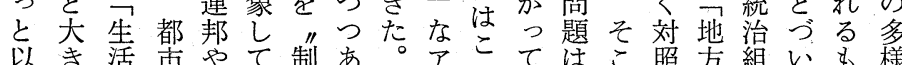
前な世洲へ度るメのまや的自織ての性 かコ界もは都花。リたたはで性治ま、での らミ店多“国妿め含りの格法で自あた

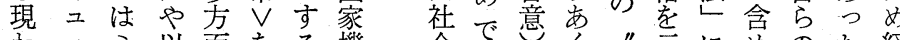
わ二ミ以面をる機会で意方系にめのた経

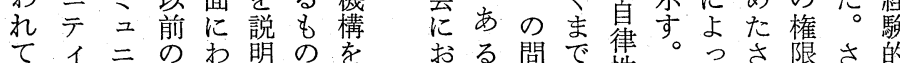

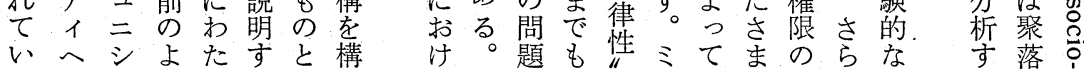

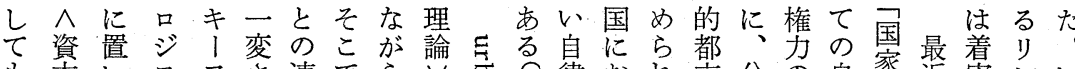

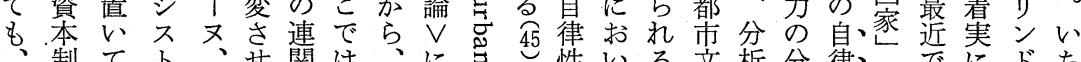
、制てト、せ関は、に寻性いる文析分律々でにドち

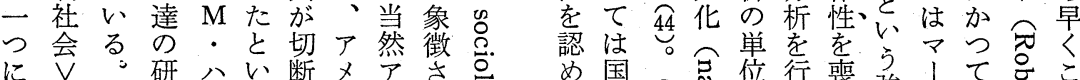
はのこ究、わさリメれ哭 、概のは口れれカリる

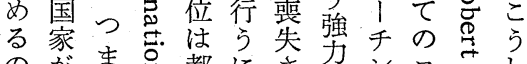
のがま号都にさ力ン口方方

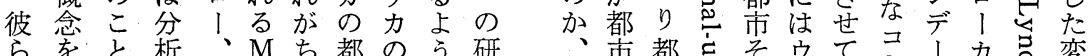

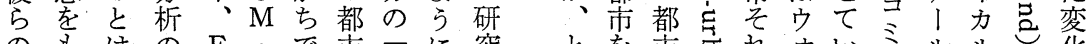
のもはの $\mathrm{E}$ ・市市に究とを市离れオいミュルルに化

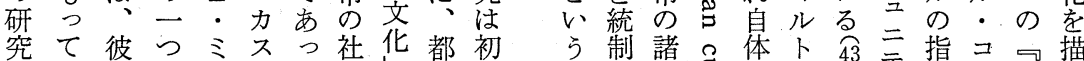

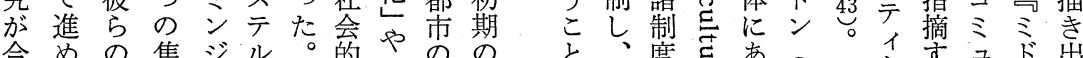
合めの焦ジル。的やのの点度吉あここをすさド出

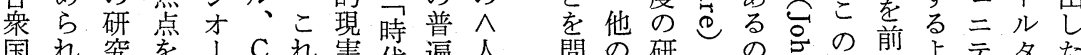
国れ究をＣＵ塞代遍人問の研のの㐓の前よテタた よてがフネ・にを的間題国究のできたにうイウの

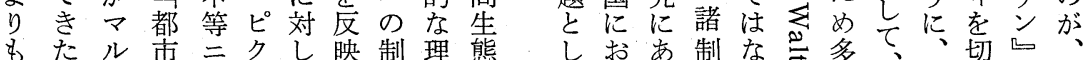
はこキしュヴてし約論学ないた度く哥様”どりで古

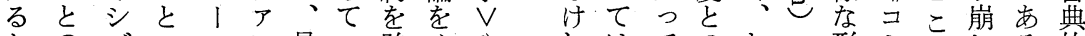

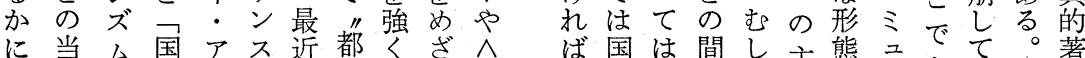
に当么国ア不近都くざ

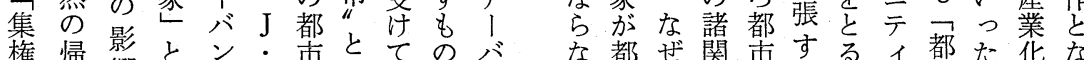

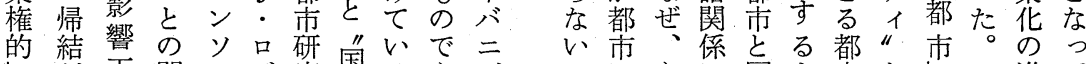
的下関シジ究国るあ⿸゙一のにあに国よ市と都進て なとに連オニを家。りム強る求家うのしは展い 
た会なてうはまめ地

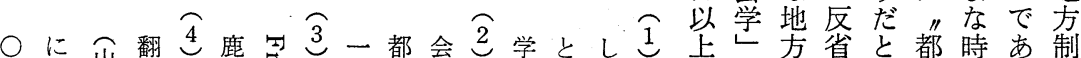

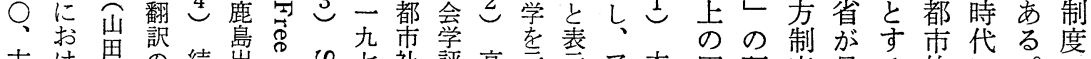
吉け田の緢出。比社評高系示了本困研度見る的に。度

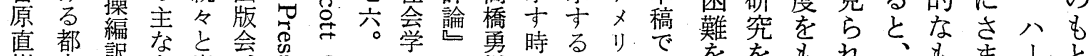
樹市䚿出出:

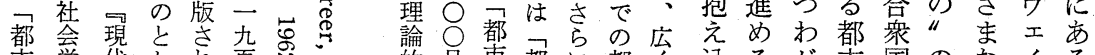

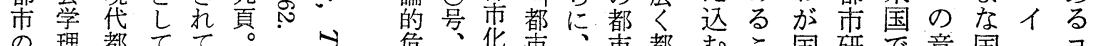

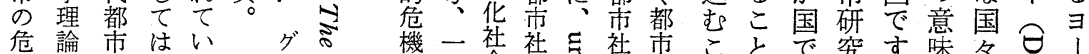

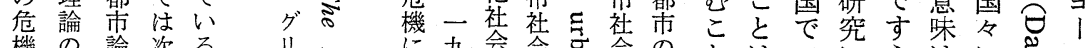

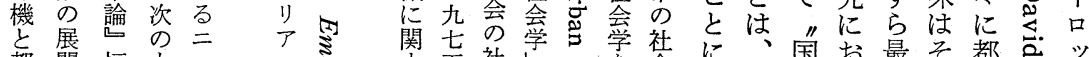

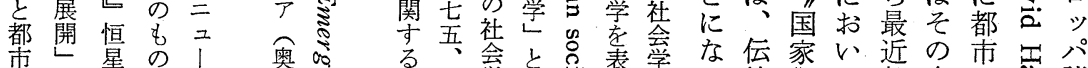

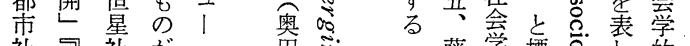

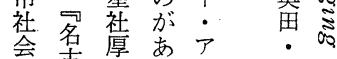

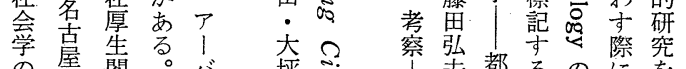

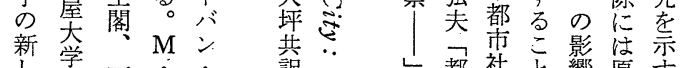

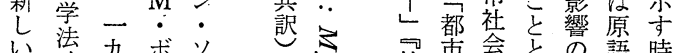

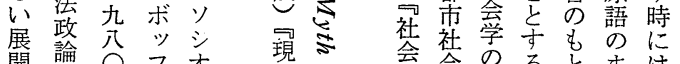

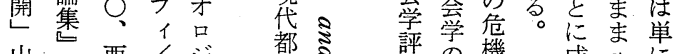
岸入西 $/$ 洔都ミ評市機盛志都

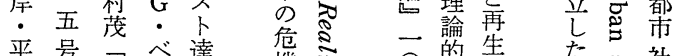

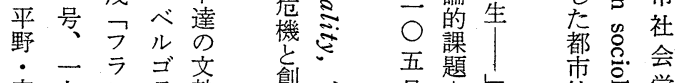

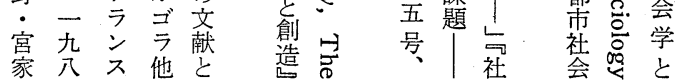
る統“て都全は器 だ的と、市体存し国 ろなのヨの的在岕の

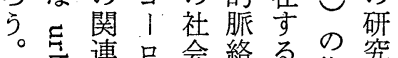
連口会絡る。指究 切パ現応だ摘ら

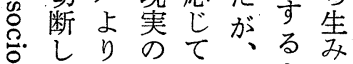
たも変変都出出 吅まさ化わ都うさ がまらにる市热

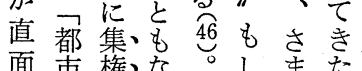
面蒂権なっし委た

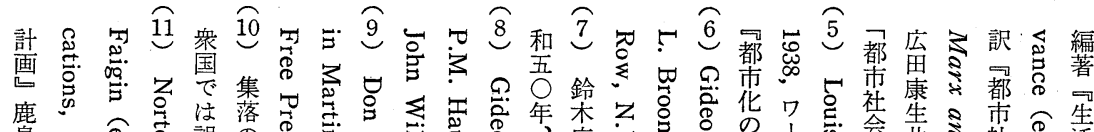

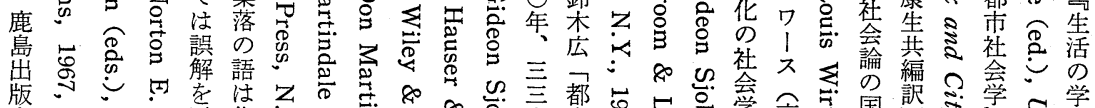

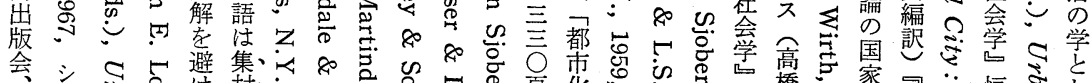

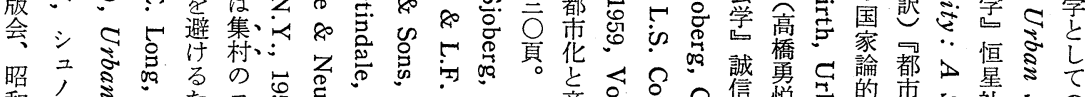

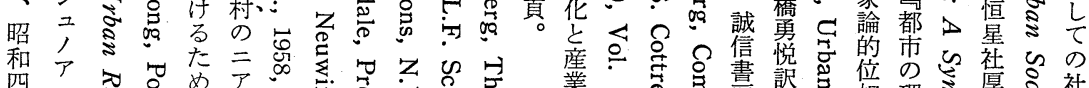

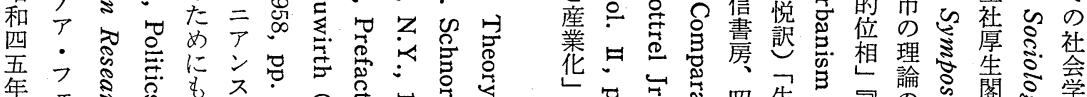
年

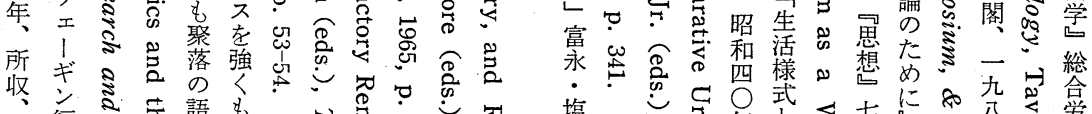

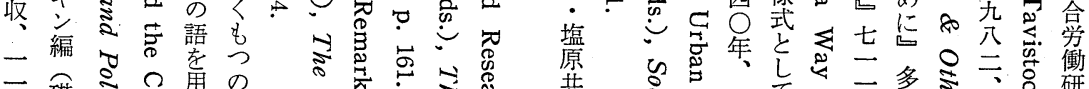

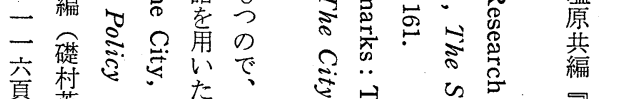

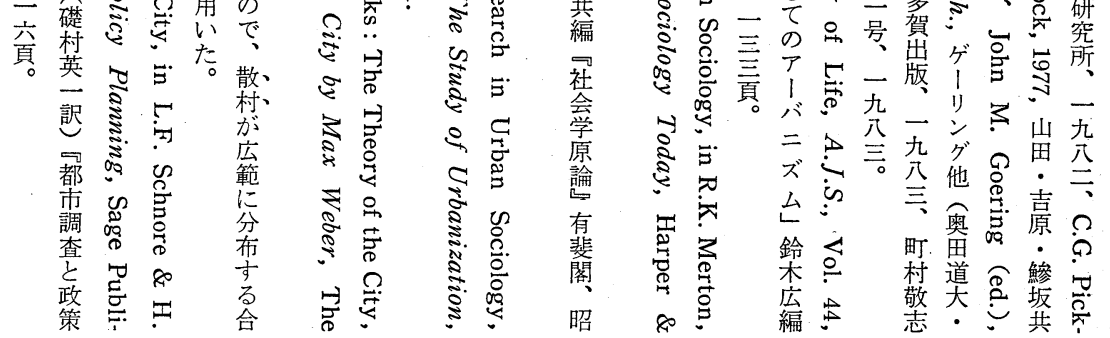




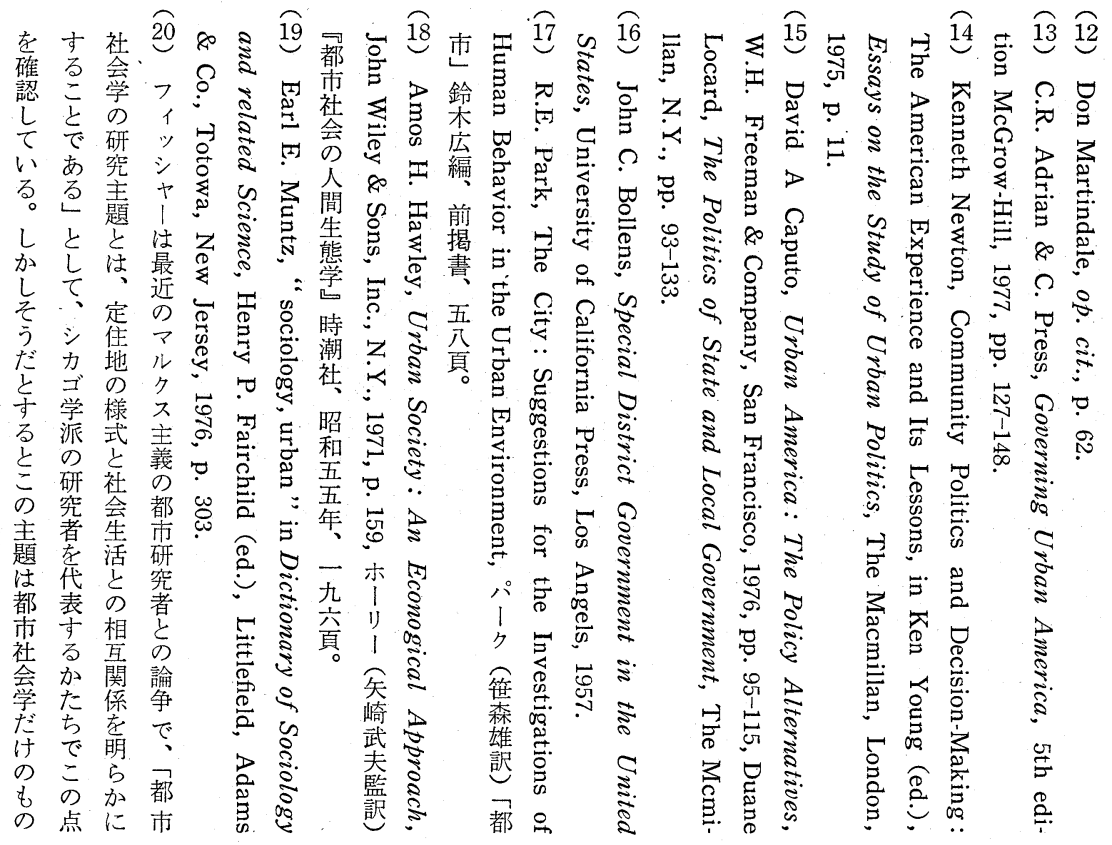

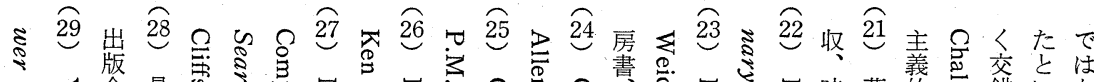

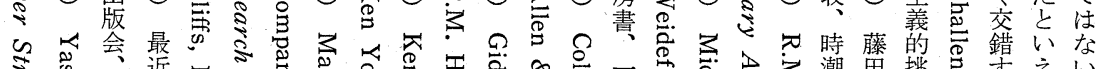

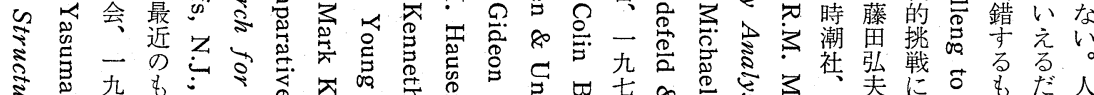

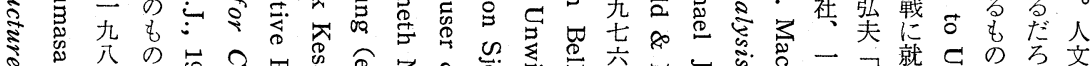

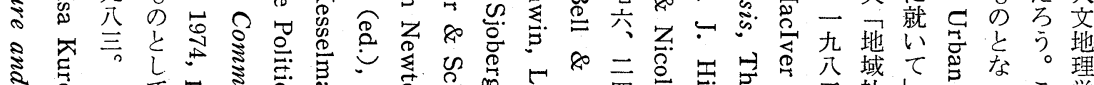

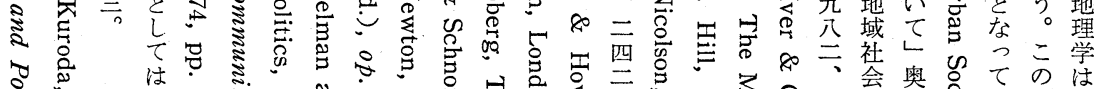

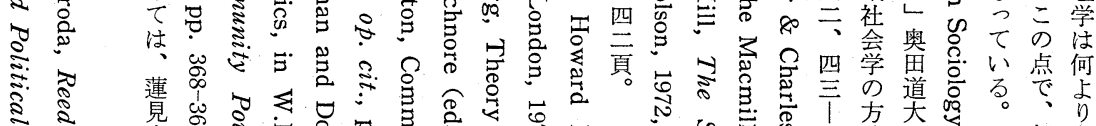

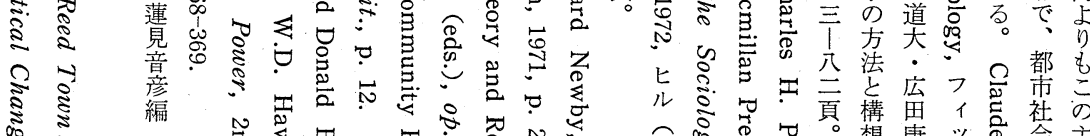

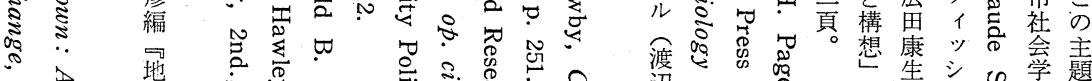

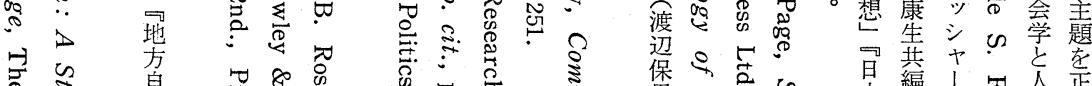

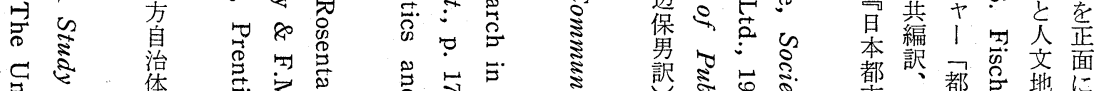

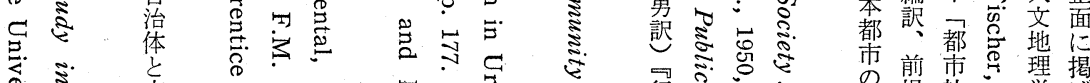

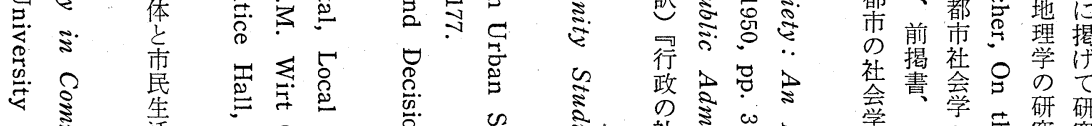
옹 活

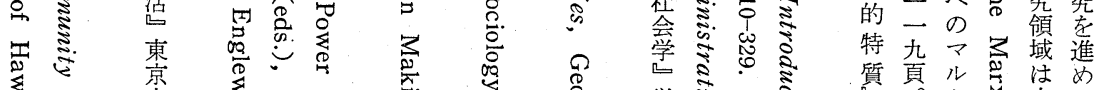

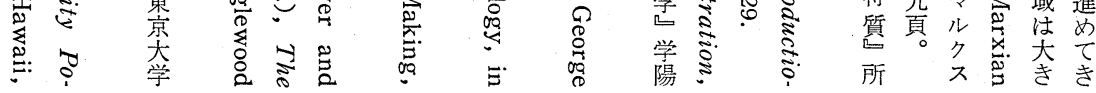




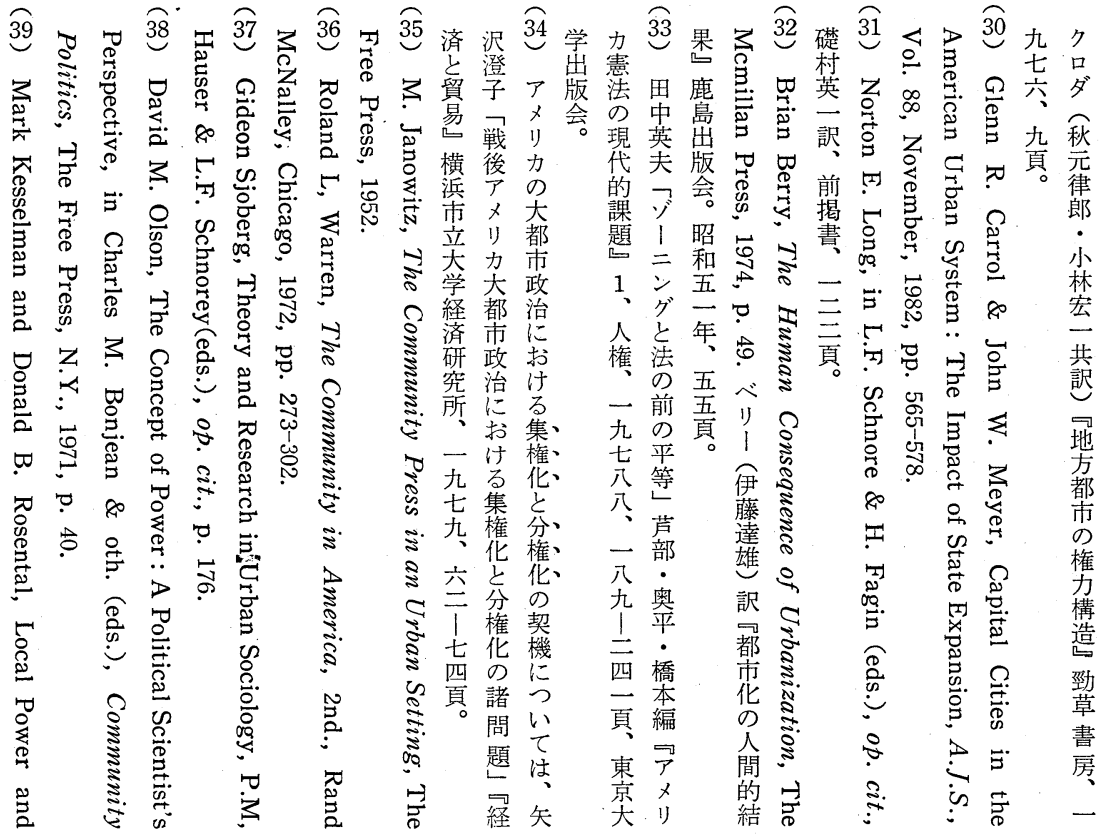

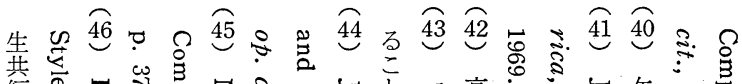

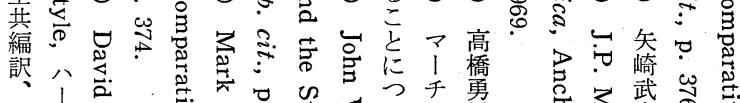

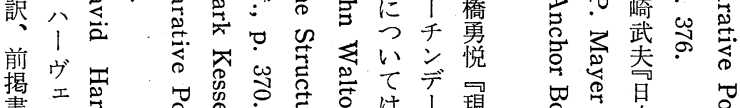

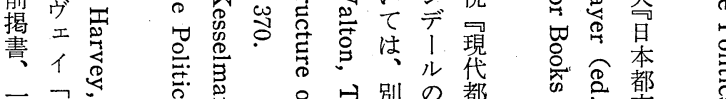

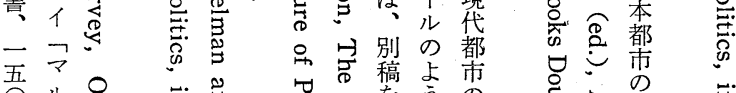

吾ル

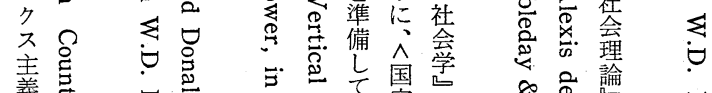

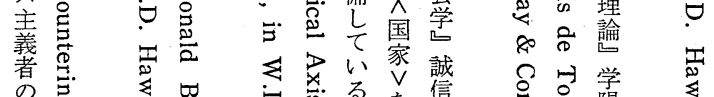

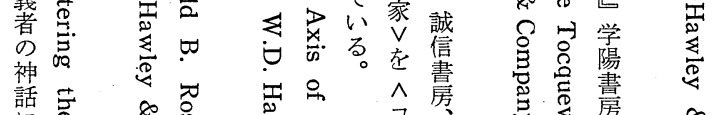

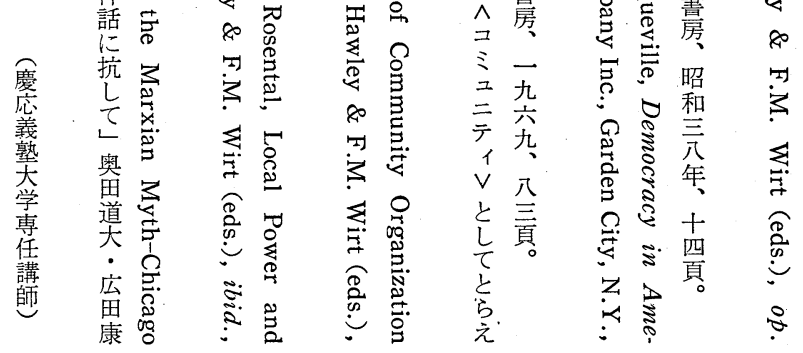




\title{
The Study of Urban Sociology
}

\author{
Hiroo Fujita \\ Keio-Gijiku University
}

Urban Sociology has a long history since it originated in the Chicago School. In analyzing the city social system, Urban Sociology has not taken into full account the connection between its own system and the overall social system (nation state). If this is the case, where has this prevailing character of Urban Sociology come from?

From the point $I$ have raised above, this paper attempts to explain the important problems of Urban Sociology. Above all, I question whether these characteristics of Urban Sociology have been caused by the actual form of the social systems of American cities, where there are peculiar features of American society. The existing local systems of American cities are characterized by decentralization of central authority and the autonomy of local government systems, which is symbolized by the $>$ home rule $<$ system.

At any rate, American cities have unusual autonomy as compared to cities in industrialized countries. Recently these autonomous cities, working independently from the central governmont, are changing. Nevertheless the fundan. mental type of traditional American city life system has remained unchanged.

In conclusion I hope to emphasize the peculiar theoretical characteristics of Urban Sociology in relation to the overall social system (nation state) by analyzing the actual form of American city life system. 